\title{
6. SITE 307: HAWAIIAN MAGNETIC LINEATIONS
}

\author{
The Shipboard Scientific Party ${ }^{1}$
}

\section{SITE DATA}

Date Occupied: 9 September 1973 (0530Z)

Date Departed: 13 September 1973 (0650Z)

Time on Site: 97.3 hours

Position: $28^{\circ} 35.26^{\prime} \mathrm{N}, 161^{\circ} 00.28^{\prime} \mathrm{E}$

Water Depth: 5696 corrected meters (echo sounding)

Bottom Felt With Drill Pipe At: 5708 meters below rig floor Penetration: 316.5 meters

Number of Holes: 1

Number of Cores: 13

Total Length of Cored Section: 111 meters

Total Core Recovered: 19.4 meters

\section{BACKGROUND AND OBJECTIVES}

Larson and Chase (1972) used a magnetic-reversal block model based on the Phoenix lineations to correlate the Phoenix and Japanese lineations with the eastern portion of the Hawaiian lineations (anomalies M-1 to M-10). Larson and Pitman (1972) extended that model to the western portion of the Hawaiian lineations (anomalies M-11 to M-22) and used the entire model to correlate all of the Hawaiian lineations to the entire Keathley lineation set in the western North Atlantic. They then derived a magnetic-reversal time scale for these Mesozoic magnetic anomalies whose older portion depends on the basement age determined for Site 105 (Leg 11). This site lies about $100 \mathrm{~km}$ west of M-22 on the Keathley lineations and has a basement age of Oxfordian-Callovian(?), about 155 m.y. Site 307 will test the claim of Larson and Pitman (1972) that their correlation of Mesozoic magnetic anomalies is worldwide, extending from the Pacific to the Atlantic. If this claim is substantiated, Site 307 may be an important calibration point for the old end of the Mesozoic reversal time scale. The Larson and Pitman time scale predicts a Portlandian basement age for Site 307, about 140-145 m.y.

Site 307 may have been generated at a spreading ridge crest considerably south of the equator in the Late

\footnotetext{
'Roger L. Larson, Lamont-Doherty Geological Observatory, Palisades, New York (Co-chief scientist); Ralph Moberly, Hawai Institute of Geophysics, Honolulu, Hawaii (Co-chief scientist); David Bukry, U.S. Geological Survey, La Jolla, California; Helen P. Foreman, Oberlin College, Oberlin, Ohio; James V. Gardner, Scripps Institution of Oceanography, La Jolla, California; John B. Keene, Scripps Institution of Oceanography, La Jolla, California; Yves Lancelot, Lamont-Doherty Geological Observatory, Palisades, New York; Hanspeter Luterbacher, Esso Production Research-European, Begles, France; Monte C. Marshall, U. S. Geological Survey, Menlo Park, California; Albert Matter, Universitat Bern, Bern, Switzerland.
}

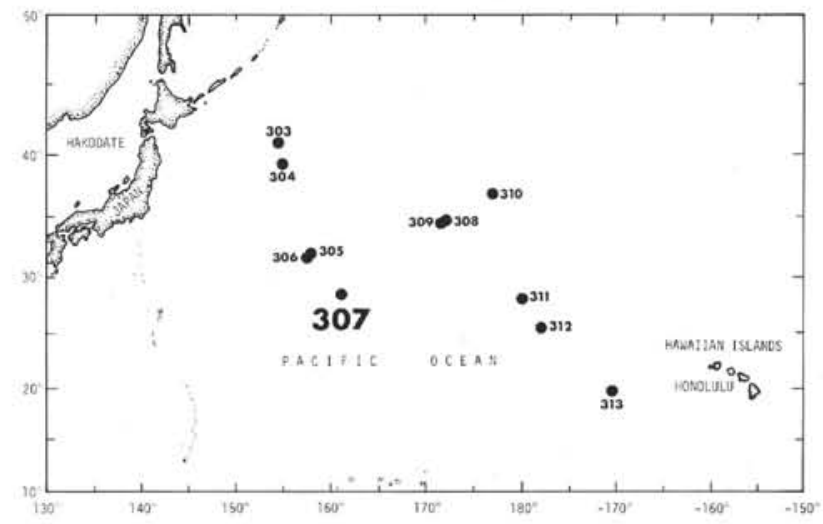

Jurassic. Thus, the sediments at Site 307 should contain carbonate and/or siliceous material that recorded the equatorial transit of Site 307. The age and nature of these "equatorial" sediments, when compared to similar material at the other geologically old sites on Leg 32 , should yield a more coherent history of the northward motion of this portion of the Pacific plate.

Reflection profiles show shallow reflectors at Site 307 that suggest the section almost certainly contains chert. The age and nature of these cherts will be studied to shed light on the equatorial transit of Site 307 and the factors involved in the chertification of these sediments.

The basaltic basement at Site 307 should be ridgecrest type tholeiite (commonly olivine-normative and very low in alkalies) with pillows and hyaloclastites which typify many previous DSDP basaltic sites. Site 307 should yield some of the oldest of these types of basalts encountered on Leg 32, and should provide an end-member to the spectrum of basalt alteration. They will also be useful to geophysicists interested in refraction seismology, to geochemists postulating the composition of subducted crust, and perhaps to geochemists interested in the transfer of transition elements from volcanic rocks to overlying sediments.

If an orientation measurement can be obtained on the basalts, it should be possible to provide an independent test of the equatorial transit of Site 307. Most reconstructions place the origin of Site 307 at about $20^{\circ} \mathrm{S}$ latitude. Thus, the remnant inclination should be about the same as the present-day value, but will not determine if the site was formed north or south of the equator. True north orientation of the sample would allow a remnant declination measurement to be made that would resolve this ambiguity.

In addition to remnant magnetization vector directions, the magnetic mineral content of the basalts, and the stability and intensity of remnant magnetization will also be of considerable interest. 


\section{OPERATIONS}

The vicinity of Site 307 (Figure 1) had been surveyed by Aries-5 and -7 expeditions, and tracks of other oceanographic ships had passed nearby, so we were able to keep our survey efforts to a minimum (Figure 2). Glomar Challenger approached from the northwest, from Shatsky Rise. Upon intercepting an Aries-7 track near the $161^{\circ} \mathrm{E}$ meridian, we turned south to parallel the track and slowed our speed to about 5 knots. The location we selected, on the basis of our airgun profile, appeared to have about $0.07 \mathrm{sec}$ of transparent sediment over the first hard reflector (Figure 3 ). We executed a Williamson turn to put us back along our track and dropped a presoaked acoustic beacon at $1630 \mathrm{hr}$ on 9 September 1973 (0530Z), in 5696 meters depth of water, corrected from a PDR depth of $3014 \mathrm{fm}$. We retrieved the geophysical gear, maneuvered back over the beacon, and commenced running the drill string.

A sonobuoy was run on 10 September 1973, but the lack of a current precluded the reception of good information, so it was terminated after about $2 \mathrm{hr}$ of operation.

When the site was abandoned, we got underway at $1750 \mathrm{hr}$ on 13 September 1973 by first steaming to the southwest while streaming our geophysical gear, and then turning to the northeast and surveying across the beacon enroute to our next site (Figure 3).

A standard assembly of roller bit, drill collars, and bumper subs was assembled, except that the lowest drill collar was monel as we intended to orient basement cores. The pneumatic tongs were used in joining the lengths of drill pipe so that for this deep-water site about $2 \mathrm{hr}$ of time were saved.

A core at the sea floor was retrieved, with most of the cored interval recovered. This first core, and the last one, in basement, were the only two with good recovery

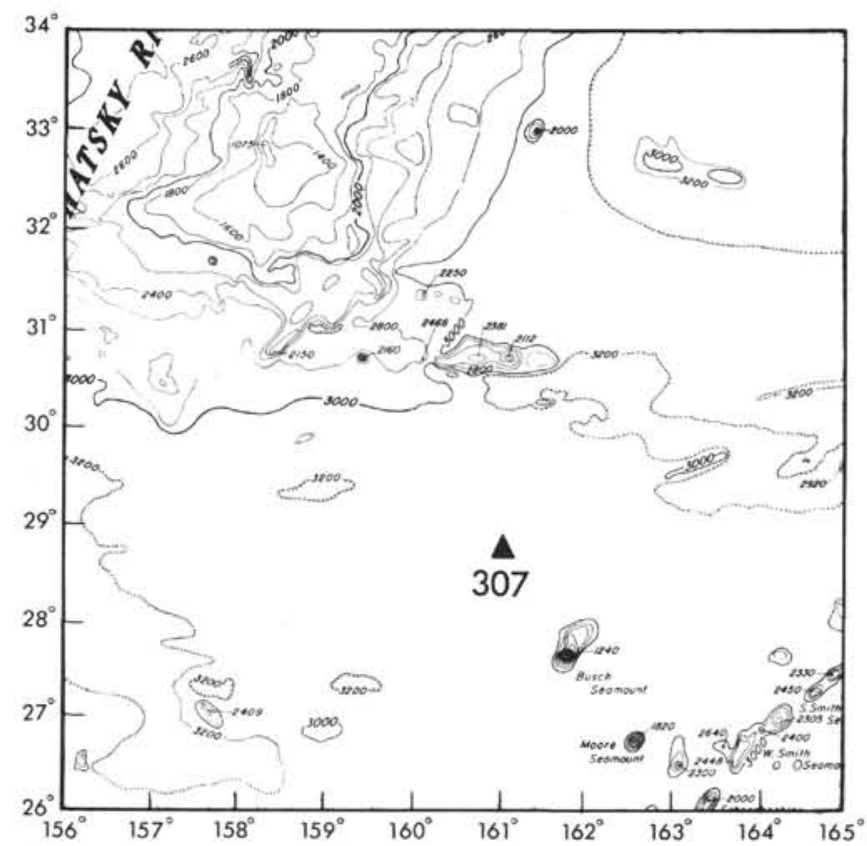

Figure 1. Bathymetry in the region of Site 307 (after Chast et al., 1971). Contour interval $200 \mathrm{fm}$ uncorrected.

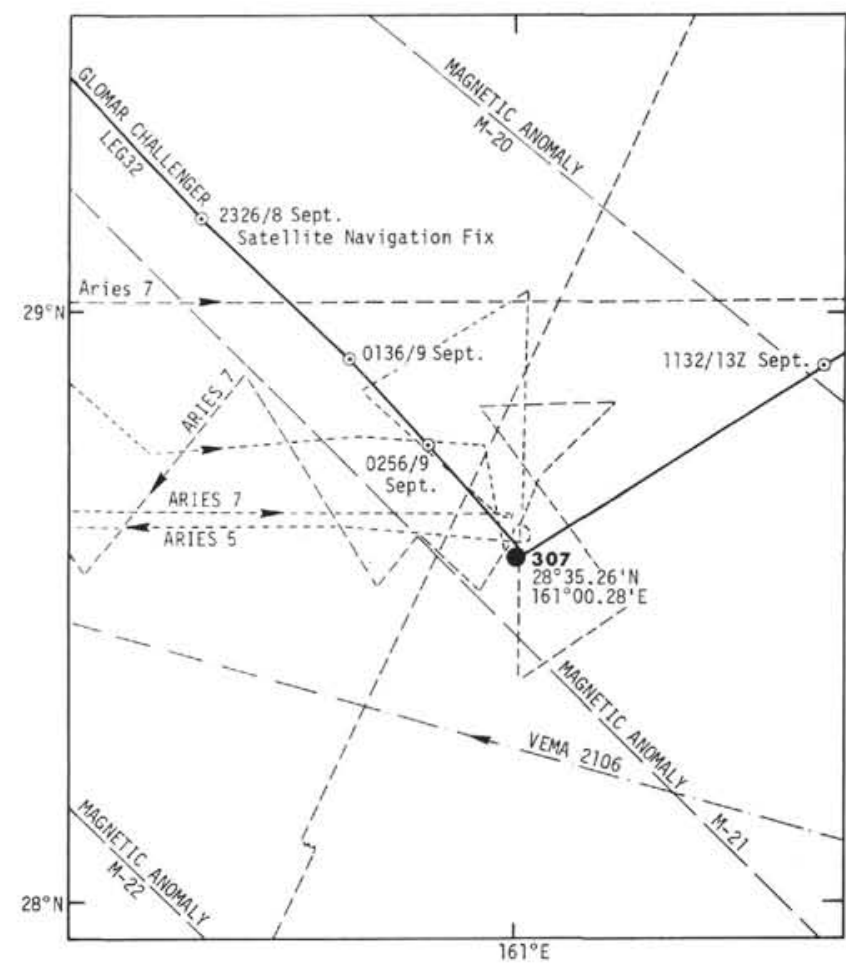

Figure 2. Track chart in vicinity of Site 307. Solid track is Leg 32 Glomar Challenger; long dashed track is Conrad1007; dash-dot track is Vema-2106; short dash track is Aries-7; dot track is Aries-5. Open circles are Glomar Challenger navigation points annotated with time/daymonth. Identified magnetic anomalies are indicated as long dashes.

(Table 1). A hard layer was encountered at 33 meters, slightly shallower than anticipated. For the next several hours, our drilling and coring was slow and careful in order to bury the bottom-hole assembly before unduly straining it and risking a failure. The interval from 65 to 85 meters was fairly soft, but most of the rest was hard. A center bit was used while drilling the depth of one of the lengths of pipe. The hard chert and porcellanite interlayered with soft chalk and clay needed modest pump pressures to remove the chert cuttings, and thereby washed away almost all the soft sediment. Even so, when the pumped circulation would have to be stopped while connecting each length of pipe, the bit would plug partially from cuttings that had not been circulated up the annulus.

When the string was pulled up a few meters off bottom to retrieve Core 9, the bit plugged and became stuck in the hole. After a few hours of attempting to lift, drop, or rotate the bit, it finally was worked free by pulling at a tension of about $550,000 \mathrm{lb}$ on the draw works. The bit stuck again for about $1.5 \mathrm{hr}$ after cutting Core 12, and again $550,000 \mathrm{lb}$ of pull was needed to free it. The bottom of Core 13, which ultimately proved to be the total depth at Site 307, was at 316.5 meters.

Because we had not been able to recover any soft calcareous sediment within 30 meters of basement, we next attempted to recover a side-wall sample close to basement in order to meet our objective of dating the 


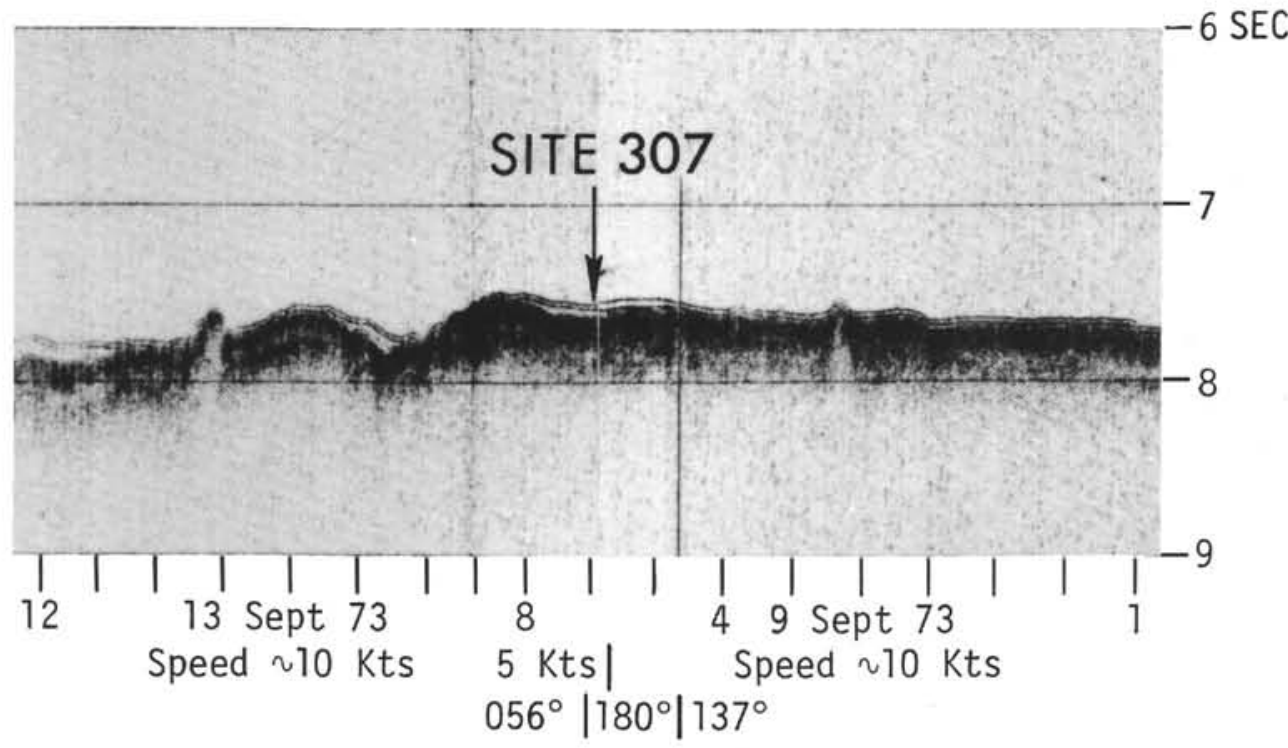

Figure 3. Seismic profiler section approaching and leaving Site 307.

TABLE 1

Coring Summary

\begin{tabular}{|c|c|c|c|c|c|c|c|}
\hline Core & $\begin{array}{l}\text { Date } \\
\text { (Sept. } \\
1973 \text { ) }\end{array}$ & Time & $\begin{array}{c}\text { Depth } \\
\text { From Drill } \\
\text { Floor (m) }\end{array}$ & $\begin{array}{l}\text { Depth Below } \\
\text { Sea Floor }(\mathrm{m})\end{array}$ & $\begin{array}{l}\text { Length } \\
\text { Cored } \\
\text { (m) }\end{array}$ & $\begin{array}{l}\text { Length } \\
\text { Recovered } \\
\text { (m) }\end{array}$ & $\begin{array}{c}\text { Recovery } \\
(\%)\end{array}$ \\
\hline 1 & 10 & 0535 & $5708.0-5717.0$ & $0.0-9.0$ & 9.0 & 7.5 & 83 \\
\hline 2 & 10 & 0930 & $5745.5-5755.0$ & $37.5-47.0$ & 9.5 & 0.4 & 4 \\
\hline 3 & 10 & 1245 & $5764.5-5773.5$ & $56.5-65.5$ & 9.0 & 0.4 & 4 \\
\hline 4 & 10 & 1700 & $5792.5-5793.5$ & $84.5-85.5$ & 1.0 & 0.2 & 20 \\
\hline 5 & 11 & 0035 & $5811.0-5820.5$ & $103.0-112.5$ & 9.5 & 0.1 & 1 \\
\hline 6 & 11 & 0355 & $5829.5-5838.5$ & $121.5-130.5$ & 9.0 & 0.3 & 3 \\
\hline 7 & 11 & 0820 & $5866.0-5875.0$ & $158.0-167.0$ & 9.0 & 1.7 & 19 \\
\hline 8 & 11 & 1255 & $5903.0-5912.0$ & $195.0-204.0$ & 9.0 & 1.2 & 13 \\
\hline 9 & 11 & 2135 & $5940.5-5949.5$ & $232.5-241.5$ & 9.0 & 1.3 & 14 \\
\hline 10 & 12 & 0225 & $5978.0-5987.0$ & $270.0-279.0$ & 9.0 & 0.8 & 9 \\
\hline 11 & 12 & 0615 & $5996.5-6005.5$ & $288.5-297.5$ & 9.0 & 0.7 & 8 \\
\hline 12 & 12 & 0820 & $6005.5-6015.0$ & $297.5-307.0$ & 9.5 & 0.6 & 6 \\
\hline 13 & 12 & 1450 & $6015.0-6024.5$ & $307.0-316.5$ & 9.5 & 4.2 & 46 \\
\hline Total & & & & & 111.0 & 19.4 & 17.5 \\
\hline
\end{tabular}

oldest sediments at the site. We planned to follow that operation with two deeper cores into basement for basalt samples rather than for oriented cores, as we knew by then that it would be impossible to attempt core orientation with the plugging and sticking troubles we had been experiencing.

Of our four unsuccessful attempts to obtain a sidewall sample, on the first, the cable pulled from its socket leaving the sampler as junk in the hole which then ruled against any later coring into basement. The next sampler's coring tube did not open, and the third did not recover any sample. While the fourth was being retrieved with the overshot and wire line, a hydraulic line on the Bowen power unit carried away. By the time the oil was cleaned from the rotary floor for safe working conditions and repair made to the hydraulic and air systems, apparently the core barrel, holding the sampler, unscrewed itself and fell down the drill string, so that only the overshot and uppermost fittings of the core barrel were recovered on the line. There was then nothing else that could be done except to pull out of the hole.

Magnifluxing the drill collars and bumper subs, which had been severely strained when the bit stuck, was necessary and added about $5 \mathrm{hr}$ more to our time on site.

When the side-wall sampler came up with the bit it was empty. The bit had suffered moderate wear.

\section{LITHOLOGIC SUMMARY}

The stratigraphic section drilled at Site 307 was discontinuously sampled down to Core 11 and continuously cored from Cores 11 to 13 . At the base of Core 12 the uppermost portion of the basement was sampled and consisted of extremely altered basalt. Altered basalt was also recovered from Core $13(307-316.5 \mathrm{~m})$. The total depth of the hole was 316.5 meters and it was drilled in 5696 meters of water. 
The recovery was relatively poor in all cores with the exception of Cores 1 and 13 . The poor recovery was due to the occurrence of abundant chert in unconsolidated sediments. It was not possible to determine the relative amounts of chert and adjacent lithologies. The composition of selected lithologies is shown in the smear slide summary, (Table 2).

The section can be divided into three sedimentary units overlying igneous basement.

Unit 1 -Zeolitic pelagic clay $(0-9 \mathrm{~m}$, Core 1$)$.

Unit 2-Chert, porcellanite, and zeolitic pelagic clay (37.5-130.5 m, Cores 2 through 6).

Unit 3-Chert, nanno chalk, and calcareous porcellanite (158-298 m, Cores 7 through part of 12).

Unit 4-Altered, fine-grained basalt and hyaloclastite (298-316.5 m, part of Core 12 and Core 13).

\section{Unit 1-Zeolitic Pelagic Clay (Core 1)}

This unit probably extends down to 33 meters where hard drilling, indicating chert, was first encountered. The sampled section is a typical brown zeolitic pelagic clay. It is generally unfossiliferous with the exception of fish remains and fragments of Radiolaria. With the exception of rare Quaternary species at the surface, the radiolarian fragments are no longer optically amorphous, the opal having crystallized to opal-CT (Jones and Segnit, 1971) or chalcedony. The fish debris range in size up to $2 \mathrm{~mm}$.
The zeolite present is phillipsite and forms ragged subhedral crystals in the upper part of the core whereas in the lower part of the core the crystals are euhedral and commonly are twinned. The abundance of phillipsite increases with depth in the core and there is a corresponding increase in size from an average of $20 \mu \mathrm{m}$ to an average of $60 \mu \mathrm{m}$. Manganese micronodules (10 to $200 \mu \mathrm{m})$ are also present.

Silt-size detrital quartz, feldspar, and volcanic glass make up less than $5 \%$ of the sediment. The volcanic glass is mainly colorless with lesser amounts of yellowishgreen glass.

Unit 2-Chert, Porcellanite, and Zeolitic Pelagic Clay (Cores 2 through 6)

The first chert sampled was in Core 2. However, as mentioned earlier, the drilling rate data suggest the first chert horizon to be at 33 meters. The dominant lithologies sampled in this unit were porcellanite and chert. Porcellanite in the hand specimen is a less dense, porous chert with a porcellaneous luster rather than a vitreous luster. In thin section, the porcellanite consists of opal-CT and minor chalcedony with the chalcedony mainly as internal molds of Radiolaria (see also Keene, this volume).

The porcellanites have a wide range of colors from yellowish-brown to grayish-orange and are generally thinly laminated $(2-4 \mathrm{~mm})$ with sharp contacts between

TABLE 2

Smear Slide Summary, Site 307

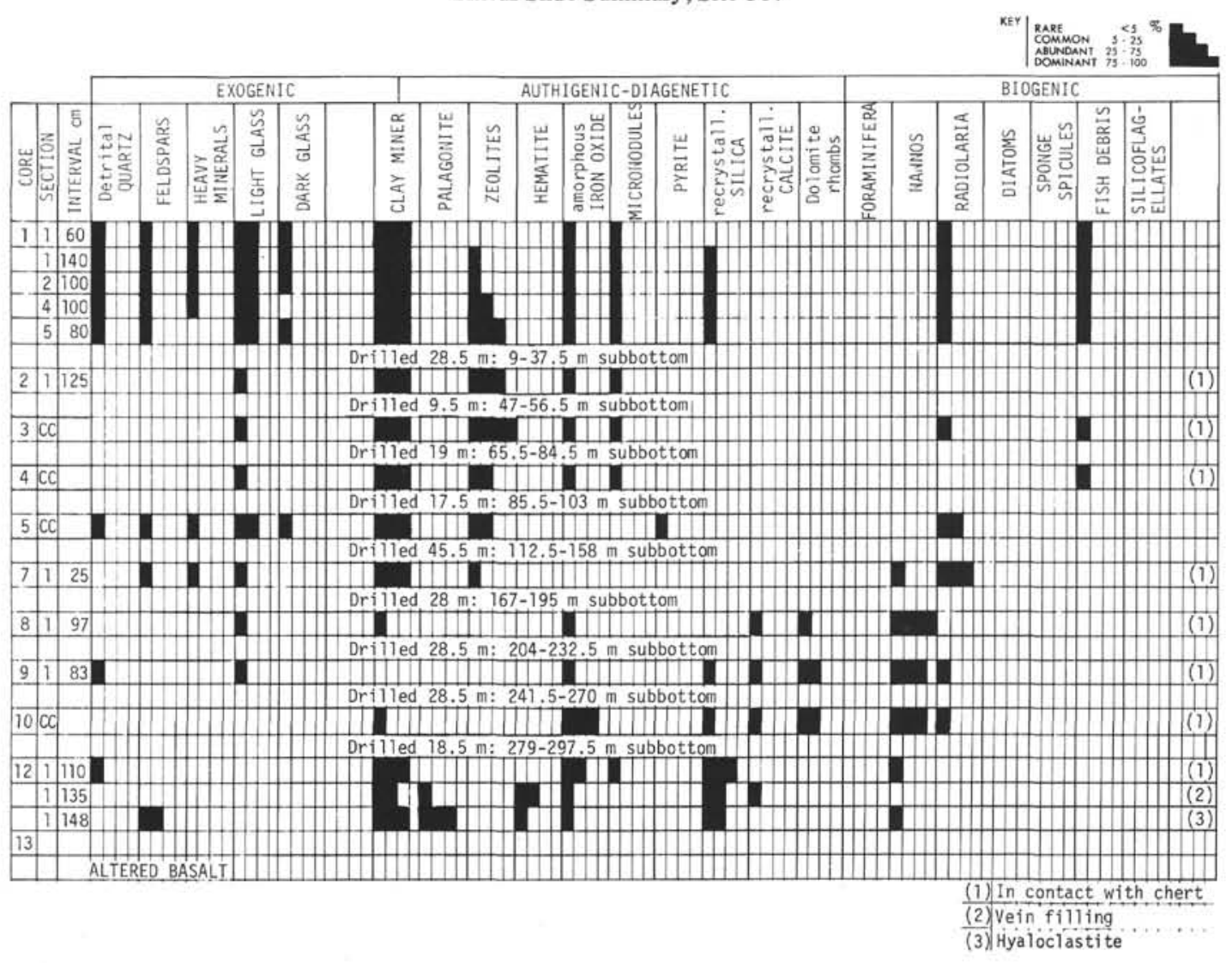


the laminae. Some samples show sharp contacts between porcellanite and zeolitic clay (Core 2) and porcellanite and chert (Core 6). There is a general increase in the number of radiolarians with depth in this unit, although on a smaller scale the distribution of radiolarians varies from lamellae to lamellae.

The chert is generally shades of reddish-brown or yellowish-brown, is both laminated and massive and commonly contains fracture fillings or veins of gray chalcedony, and manganese dendrites are common on fracture surfaces. Irregular-shaped vugs, usually lined with porcellanites, become common in Core 6 . A chert sample from Core 2 contains a vug lined with banded botryoidal chalcedony and small quartz crystals.

Only a small amount of light brown zeolitic clay was sampled from this unit. It generally formed a thin, semilithified to soft layer on chert or porcellanite; the contact is flat and sharp. The zeolite is generally in the form of stumpy prismatic crystals with ragged edges and generally less than $10 \mu \mathrm{m}$ in length. X-ray diffraction identified the zeolite as clinoptilolite, and it is associated with minor amounts of colorless volcanic glass.

A lithology different from the ones described above composed the entire sample from Core 5. It consisted of a core-catcher sample of semilithified radiolarianbearing altered volcanic ash and was greenish-yellow in color. The sample is mainly clay and Raidolaria with minor amounts of colorless volcanic glass and clinoptilolite. The radiolarian fragments are interesting in that they have remained optically and X-ray amorphous, none having crystallized to opal-CT.

\section{Unit 3-Chert, Nanno Chalk, and Calcareous Porcellanite (Core 7 through part of 12)}

The first carbonate recovered from this hole occurs as drusy calcite filling a vein in chert from Core 7 . However, nanno chalk was first sampled in Core 8. The very little nanno chalk that was sampled was usually attached to chert or porcellanite. The contact between the lithologies is sharp. Dolomite rhombs occurred in the nanno chalk wherever it was sampled (Cores 8, 9, 10, 12). The rhombs are usually less than $30 \mu \mathrm{m}$ in size but may range up to $100 \mu \mathrm{m}$. In Cores 9 and 10 most have corroded and pitted surfaces. The nanno chalk is orange-pink.

The chert in this unit is colored shades of brown and reddish-brown and is usually mottled and contains irregular patches of silicified carbonate. Compared to Unit 2 there are fewer veins and fractures; however, Cores 8 and 12 do have chert fragments containing chalcedony veins and vugs lined with quartz crystals. A vug in Core 12 is lined with euhedral barite crystals. Radiolaria are present in the cherts from Cores 8,9 , and 10 , but their distribution varies within chert pieces. The cherts from Core 10 are particularly vitreous and flintlike.

The calcareous porcellanite is usually shades of bluish-gray or pinkish-brown. It is generally laminated and contains Radiolaria. Vugs and mottling are rare when compared with the adjacent cherts. Most of the calcareous porcellanite occurs near the top of this unit in Cores 9 and 10.
The lithologies in Cores 11 and 12 at the base of this unit are characterized by reddish ferruginous staining which coats grains and forms thin veins.

\section{Unit 4-Altered, Fine-grained Basalt and Hyaloclastite (Part of Core 12 and Core 13)}

The basement at this site is altered, very fine-grained basalt interbedded with hyaloclastite. The $40-\mathrm{cm}$ to 1 meter-thick hyaloclastite beds, as well as altered glassy selvages, divide the basalt into six cooling units, 20-70 $\mathrm{cm}$ thick. (These thicknesses are recovered amounts and are therefore minimum values.)

Much of the basalt is fairly severely weathered, especially towards the top of the basement. The alteration in Core 12 is intense, the plagioclase and pyroxene have been totally altered to montmorillonite, celadonite, and chlorite. That the clay was derived from basalt is evidenced by the fact that the alteration products have retained the intergranular texture of plagioclase laths and pyroxene grains, the skeletal forms so characteristic of magnetite, and even by ghosts of the plagioclase glomerophenocrysts found in the basalt of Core 13. The degree of alteration generally decreases with depth. Some of the plagioclase and opaques still remain in the basalt at the top of Core 13, whereas both the silicates and opaque minerals in some of the basalt in cooling Units 3 and 4 (upper half of 13-1) appear largely unaltered. The color of the basalt varies with the degree of alteration, changing from a dark gray in the freshest basalt to a light greenish-gray in the highly altered basalt. The clay in Core 12, in turn, varies from a light brownish-gray at the base to a grayish-red at the top because of the addition of goethite(?).

The glassy selvages are now almost completely altered to dark green, flakey, waxy celadonite and montmorillonite. These 1 to $2 \mathrm{~cm}$-thick green zones, interlayered with calcite veins, mark the cooling unit (pillow?) margins. A 1 to $2 \mathrm{~mm}$ thick band of light gray varioles (commonly with a purplish tint) at the base of the green celadonite layers proves them to be altered glassy crusts and not simply veins. Near the base of several of the altered glass crusts, small (several mm) patches of vitreous, black glass still remain.

The basalt is highly fractured, the average fracture spacing being about 1 to $2 \mathrm{~cm}$. There are two sets of fractures. There is an older set of high angle fractures, probably cooling joints, which provided access to the seawater needed for weathering as well as some carbonate matrix that included nannofossils, and they are bordered by a 1-cm-thick band of darker green and more highly altered basalt. Following the alteration of the basalt and cementation with calcite of these fractures and the breccia, a second set of low angle fractures was generated, which, in turn, was filled with calcite.

The hyaloclastite is composed of fragments of altered glass $(0.1-1 \mathrm{~cm})$ and basalt $(1-4 \mathrm{~cm})$. The basalt fragments typically have altered glassy crusts on at least one of their surfaces. The clasts are well cemented with calcite and celadonite. A cavity $2 \times 5 \mathrm{~cm}$ and lined with calcite and drusy quartz occupies most of one of the core segments in 13-3. 


\section{Conclusions}

Because of the spot coring, poor recovery, and lack of fossils, sedimentation rates for this site are merely approximate and this makes the recognition of unconformities difficult. Between fossil dates of Quaternary in the uppermost 0.5 meter of Core 1 , and early Late Cretaceous in Core 2, there are only 37 meters of sediment. The water depth and the location of this site in the low productivity area of the North Pacific would result in slow or nondeposition during the Tertiary. The zeolitic brown clay of this upper unit is typical of very slow rates of sedimentation. However, unconformities are known elsewhere in the northwest Pacific, and part of the compressed section may be due to one or more unconformities.

The occurrence of cherts and Radiolaria in Unit 2 indicates an increased sedimentation rate. More radiolarian tests reaching the sea floor reflect increased productivity in the surface waters. However, within this unit there is also nonfossiliferous zeolitic clay which either represents periods when no siliceous fossils were deposited or their siliceous remains have been removed by solution. The cherts in Unit 2 probably form beds or lenses. Evidence for this is the bedding and laminae in many of them and the flat contacts with the adjacent clay or porcellanite.

The occurrence of nannofossils in Unit 3 means that deposition occurred above the calcite compensation depth. The unit is characterized by a decrease in the ratio of porcellanite to chert and an increase in vugs, inclusions, and mottling compared to Unit 2. In Unit 3 the chert is hard, vitreous, massive, has irregular surfaces, and is composed of chalcedony or quartz as opposed to the opal-CT and chalcedony of the cherts in the clayrich Unit 2. This change in the cherts is reflected in the increased sonic velocities for the chert from Unit 3 (e.g., Core 9) compared to the cherts in Unit 2.

Dolomite rhombs were found in the carbonate sampled at 195 meters. The sediment is the same Valanginian to Hauterivian age as the dolomite-bearing carbonate first recovered at Site 306 at 253 meters.

In general, lithification at Site 307 varies with sediment type rather than depth. An exception is immediately above basement where there is increased lithification of all sediments due to ferruginous cement.

Although both sedimentary and igneous rocks were recovered in Core 21 , their actual contact was destroyed during drilling. The choice of 298 meters as the basement contact was based on a change in the drilling rate. The thin units of glassy, very fine-grained basalt, interbedded with hyaloclastite beds as much as 1 meter thick, strongly suggest that this volcanic unit is extrusive and represents the top of layer 2 of the oceanic crust.

\section{PHYSICAL PROPERTIES}

\section{Wet Bulk Density and Porosity of Soft Sediments}

The recovery of soft sediments at this site is essentially restricted to Core 1 , and the drilling disturbance here is described as "severe." The density of this zeolitic pelagic clay, measured by the GRAPE on Sections 2, 3, and 4, is practically constant at $1.4 \mathrm{~g} / \mathrm{cc}$. The density of the single syringe sample $(1.41 \mathrm{~g} / \mathrm{cc})$ taken in Section 2 agrees quite well with the GRAPE value $(1.37 \mathrm{~g} / \mathrm{cc})$. Combining the syringe data and the GRAPE record, the porosity of the zeolitic pelagic clay is fairly constant at $80 \%$.

\section{Velocity Measurements}

The compressional wave velocity, $V p$, of the various lithologies recovered at this site was measured on a Hamilton frame. As at previous sites on this leg, the $V p$ of the clay of Core 1 is $1.6 \mathrm{~km} / \mathrm{sec}$. Two samples of pelagic claystone and a porcellanite have only slightly higher velocities, 1.8 and $2.3 \mathrm{~km} / \mathrm{sec}$, respectively. The velocities of the cherts in the upper part of this section are abnormally low, relative to those measured at previous sites on this leg. The $V p$ of this subvitreous chert is only 2.6 to $3.2 \mathrm{~km} / \mathrm{sec}$ in Core 3 and $3.4 \mathrm{~km} / \mathrm{sec}$ in Core 4. The cherts in Cores 7 and 9 have more typical velocities of 4.4 to $5.0 \mathrm{~km} / \mathrm{sec}$. The $V p$ of the finegrained, highly fractured and altered basalt recovered at this site is about $4.8 \mathrm{~km} / \mathrm{sec}$ and decreases to about 3 $\mathrm{km} / \mathrm{sec}$ in the upper part where intense weathering has almost reduced the basalt to claystone. The $V p$ of the well-cemented hyaloclastite that comprises almost half of the recovered basement is about $4 \mathrm{~km} / \mathrm{sec}$.

\section{GEOCHEMICAL MEASUREMENTS}

Due to poor core recovery and lithified sediments, only one interstitial water sample was taken from this site. The sample was from 6 meters below the sea floor. The $p \mathrm{H}$, alkalinity, and salinity for the sample are given in Table 3.

\section{CORRELATION OF SEISMIC REFLECTION PROFILES WITH DRILLING RESULTS}

Seismic profiles recorded while approaching and leaving (Figure 3 ) the site show a relatively thin transparent layer $(0.07 \mathrm{sec})$ overlying a thick $(0.20 \mathrm{sec})$ highly reverberative layer (opaque layer) and, barely discernible at $0.30 \mathrm{sec}$ below the sea bottom, the acoustic basement.

The whole of the upper transparent layer, although only sampled at the top, corresponds probably to a zeolitic pelagic clay interval devoid of chert, similar to that observed in Core 1 and to that found associated with chert in Core 2. The top of the opaque layer probably correlates with the occurrence of the youngest chert. The first chert was encountered in Core 2 at 37 meters subbottom but the driller recorded the first hard layer at 33 meters. If this layer corresponds with the top of the opaque layer, the interval velocity computed for the upper transparent layer falls into unreasonably low values $(1.0 \mathrm{~km} / \mathrm{sec}$ or less). As the first core consisted of rather stiff zeolitic pelagic clay, except for the uppermost few tens of centimeters which were soupy and contrasted sharply with the rest of the sediment, it is believed that the first layers of sediments were "overcored." This comes presumably from the fact that it is almost impossible for the driller to "feel" the bottom in extremely fluid clays and that the bottom contact could 


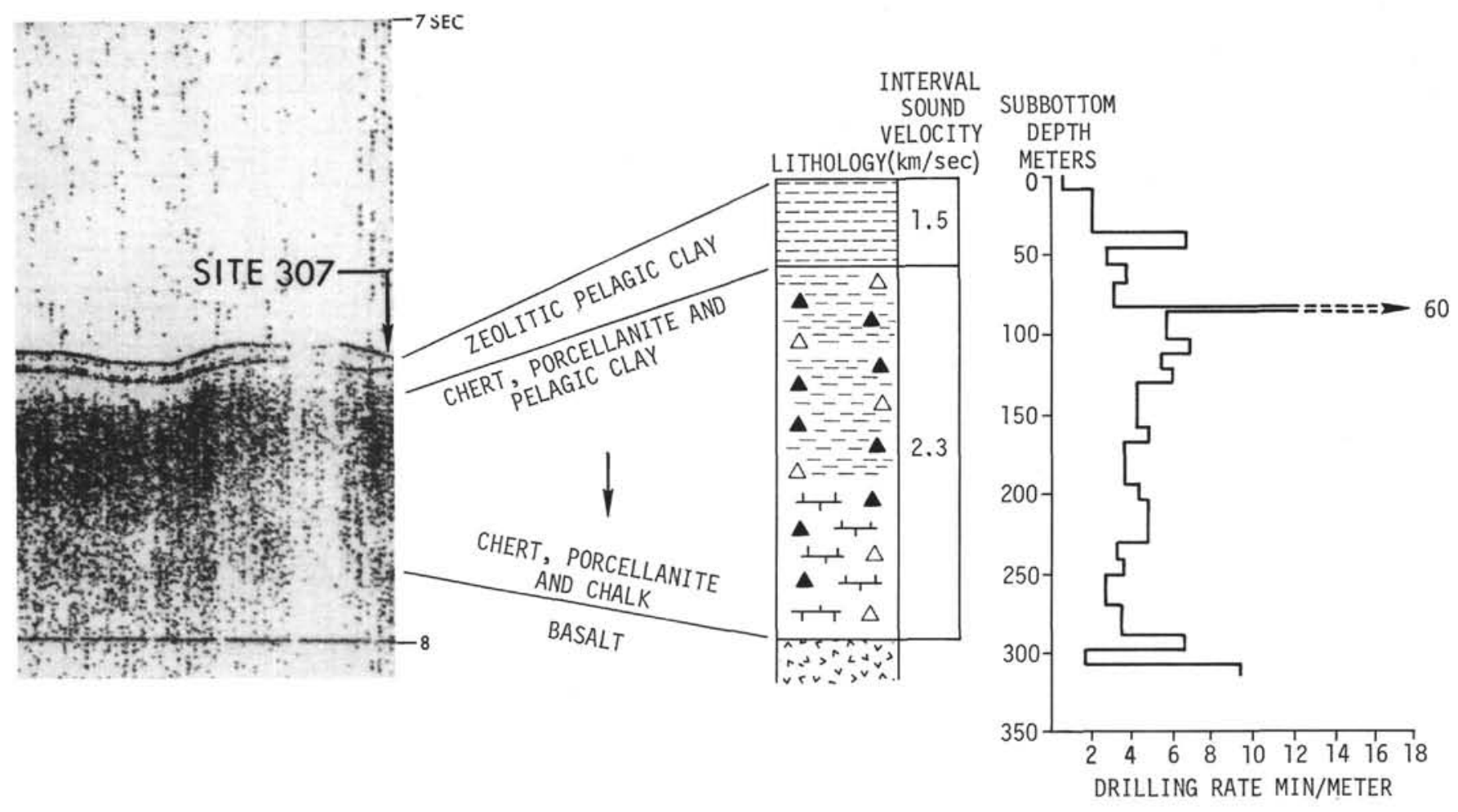

Figure 4. Correlation of seismic reflection profile with drilling results at Site 307.

TABLE 3

Summary of Shipboard Geochemical Data

\begin{tabular}{lcccccc}
\hline $\begin{array}{l}\text { Sample } \\
\text { (Interval } \\
\text { in } \mathrm{cm})\end{array}$ & $\begin{array}{c}\text { Depth Below } \\
\text { Sea Floor } \\
(\mathrm{m})\end{array}$ & $\begin{array}{c}\text { Punch- } \\
\text { in }\end{array}$ & $\begin{array}{c}\text { Flow- } \\
\text { through }\end{array}$ & $\begin{array}{c}\text { Alkalinity } \\
(\mathrm{meq} / \mathrm{kg})\end{array}$ & $\begin{array}{c}\text { Salinity } \\
(\%)\end{array}$ & $\begin{array}{c}\text { Remarks } \\
(\text { Combination } \\
\text { Electrode } p \mathrm{H})\end{array}$ \\
\hline Surface Seawater & & 8.29 & 8.27 & 2.45 & 35.2 & 8.29 \\
$1-4,144-150$ & 6 & 7.35 & 7.31 & 2.22 & 34.9 & 7.39 \\
\hline
\end{tabular}

then be observed only when the drill bit was already buried under several meters below bottom where it encountered some resistance (similar conditions have been reported several times during previous legs, especially during Leg 17). If a minimum sound velocity of 1.5 $\mathrm{km} / \mathrm{sec}$ is assumed for the upper transparent interval, the thickness of the zeolitic pelagic clay layer should be about 51 meters. If this is the real thickness for this layer, the sea bottom lies about 18 meters shallower than the depth indicated by the drill string. This is especially puzzling as the PDR depth and the drill string depth are in good agreement at this site. However, it should be kept in mind that in the deep central Pacific such a coincidence has been a rarity so far.

An interval of $0.23 \mathrm{sec}$ can be observed on the profiles between the top of the opaque layer and the acoustic basement; it probably corresponds with the chert-rich interval that makes up most of the sedimentary section. Basaltic basement was reached at 298 meters and probably corresponds with the acoustic basement. Therefore, the computed sound velocity for this interval is about $2.3 \mathrm{~km} / \mathrm{sec}$. This value seems reasonable compared to the values obtained for the most chert-rich intervals at Sites 305 and $306(2.8 \mathrm{~km} / \mathrm{sec})$ if we consider that the chert is somewhat less abundant at this site and that, at least in the upper half of the interval, is predominantly porcellanitic and relatively softer than the chert encountered on Shatsky Rise.

Figure 4 gives a summary of these correlations.

\section{BIOSTRATIGRAPHIC SUMMARY}

The oldest age for sediment at Site 307 is Valanginian to Berriasian (130 \pm 12 m.y.) based on radiolarian assemblages from lower Core 10 and Core 11. The oldest diagnostic coccolith assemblage is Valanginian or Hauterivian in Core 10 (see Table 4).

Radiolaria provide the best stratigraphic control for the 12 sediment cores cut at Site 307 . The age assignments have been determined by correlating the Radiolaria with those of Sites 305 and 306 where ages are controlled by calcareous fossils. In the Neocomian there is approximately a one-stage difference between the age assignments based on foraminifera and those based on nannoplankton. Because no value judgments can be made, the complete ranges given for both the foraminifera and the nannoplankton are used in assigning ages to the corresponding cores with Radiolaria only in Hole 307. Therefore, some rather long ranges result. 
TABLE 4

Distribution, Age, and Frequency of Investigated Microfossils

\begin{tabular}{|c|c|c|c|c|c|c|c|c|c|}
\hline \multirow[b]{2}{*}{ ن } & \multirow[b]{2}{*}{ Depth in $(m)$} & \multirow{2}{*}{ 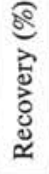 } & \multicolumn{3}{|c|}{ Foraminifera } & \multirow{2}{*}{\multicolumn{2}{|c|}{$\begin{array}{c}\text { Calcareous } \\
\text { Nannoplankton }\end{array}$}} & \multirow{2}{*}{\multicolumn{2}{|c|}{ Radiolaria }} \\
\hline & & & ี & 苞 & & & & & \\
\hline 1 & $0.0-9.0$ & 83 & - & + & - & - & & + & Pleistocene \\
\hline 2 & $37.5-47.0$ & 4 & - & + & - & - & & + & $\begin{array}{l}\text { Early Cenomanian } \\
\text { or late Albian }\end{array}$ \\
\hline 3 & $56.5-65.5$ & 4 & - & - & - & - & & 0 & Late Albian \\
\hline 4 & $84.5-85.5$ & 20 & - & - & - & + & Mesozoic (?) & 0 & Albian \\
\hline 5 & $103.0-112.5$ & 1 & - & + & - & - & & * & $\begin{array}{l}\text { Aptian/ } \\
\text { Barremian }\end{array}$ \\
\hline 6 & $121.5-130.5$ & 3 & - & - & - & + & Mesozoic (?) & 0 & $\begin{array}{l}\text { Barremian to } \\
\text { Hauterivian or } \\
\text { Valanginian }\end{array}$ \\
\hline 7 & $158.0-167.0$ & 19 & - & - & - & - & Hauterivian (?) & $\overline{0}$ & $\begin{array}{l}\text { Barremian to } \\
\text { Hauterivian or } \\
\text { Valanginian }\end{array}$ \\
\hline 8 & $195.0-204.0$ & 13 & - & - & - & - & $\begin{array}{l}\text { Early Hauteriv/ } \\
\text { late Valanginian }\end{array}$ & o & $\begin{array}{l}\text { Barremian to } \\
\text { Hauterivian or } \\
\text { Valanginian }\end{array}$ \\
\hline 9 & $232.5-241.5$ & 14 & - & - & - & $\bullet$ & $\begin{array}{l}\text { Early Hauteriv/ } \\
\text { late Valanginian }\end{array}$ & 0 & Valanginian \\
\hline 10 & $270.0-279.0$ & 9 & - & - & - & - & $\begin{array}{l}\text { Early Hauteriv/ } \\
\text { late Valanginian }\end{array}$ & * & $\begin{array}{l}\text { Valanginian/ } \\
\text { Berriasian }\end{array}$ \\
\hline$\overline{11}$ & $288.5-297.5$ & 8 & - & - & - & - & & + & $\begin{array}{l}\text { Valanginian/ } \\
\text { Berriasian }\end{array}$ \\
\hline 12 & $297.5-307.0$ & b & - & - & - & + & Mesozoic (?) & + & $\begin{array}{l}\text { Valanginian/ } \\
\text { Berriasian }\end{array}$ \\
\hline 13 & $307.0-316.5$ & b & & & & & & & \\
\hline
\end{tabular}

Note: $\bullet$ abundant; o common; $*$ frequent; + rare; - absent. b basalt

Stratigraphically useful foraminifers are absent throughout and coccoliths provide restricted ages only in Cores 8 to 10 . Only trace numbers of coccoliths are present in Cores 1 to 6 ; in deeper cores diversity is low and preservation is rated as poor. Radiolarian preservation is moderate to good in Cores 2 to 9 and poor in Cores 1 , and 10 to 12 .

A single specimen of the radiolarian Spongaster tetras at the top of Core $1(0-9 \mathrm{~cm})$ provides a Quaternary age for the upper part of the core. The next deeper assemblage is early Cenomanian or late Albian in Core 2 (38$47 \mathrm{~cm}$ ) and is associated with rare Watznaueria barnesae.

\section{Foraminifera}

The samples examined from this site contain no stratigraphically useful foraminifera. A few fragments of "Rhabdammina" occur in Core 1. The core-catcher sample of Core 2 contains a single specimen of Glomospira sp., whereas two specimens of Haplophragmoides sp. were found in the core catcher of Core 5.

\section{Coccoliths}

Samples from Cores 1 to $6(0-131 \mathrm{~m})$ are barren or contain only trace numbers of Watznaueria barnesae, the predominant Mesozoic species of coccoliths. A poor Early Cretaceous assemblage from Core $7(158-167 \mathrm{~m})$ is composed only of resistant long-ranged species.

Cores 8 to $10(195-279 \mathrm{~m})$ contain Cruciellipsis cuvillieri, indicating a Neocomian age. The Valanginian to
Hauterivian portion of the Neocomian is suggested by the presence of species of Tubodiscus in Cores 8 and 10 .

Core $11(289-298 \mathrm{~m})$ consisted only of radiolarianbearing chert. Core $12(298-307 \mathrm{~m})$ which recovered red shale and basalt altered to claystone had only rare longranged coccolith species such as Cyclagelosphaera margerelii, Diazomatolithus lehmannii, Watznaueria barnesae, and Watznaueria britannica. This assemblage suggests only an indeterminate Late Jurassic to Early Cretaceous range.

\section{Radiolaria}

Radiolaria are present in all of the cores recovered. The only Neogene sample was from the top of Core 1 where about $50 \mathrm{~cm}$ of soupy, very liquid brown clay was washed to recover some very rare, well-preserved mostly nondiagnostic Cenozoic Radiolaria. One specimen of Spongaster tetras suggests a Quaternary age. Fish teeth were common in this sample and in the core catcher.

In the Mesozoic cores Radiolaria are few to common in abundance and moderate to poor in preservation inboth chert and soft sediment samples from Cores 2 to 9 . Chert in Cores 10,11, and 13, and a mudstone sample from Core 12 contained only rare to few, poor Radiolaria.

In Core $2(37.5-47 \mathrm{~m})$ saturnalin rings and Triposphaeridae similar to those of 310A-18 suggest that these cores may be contemporaneous, and Core 2 is thus considered to be early Cenomanian or late Albian, Dictyo- 
mitra somphedia Zone. Cores 3 and 4 (56-85 m), late Albian and Albian, belong to the Dictyomitra somphedia and Acaeniotyle umbilicata Zones, respectively. A distinct change in the fauna between Cores 4 and 5 , with the last occurrence of Sphaerostylus lanceola and Dictyomitra (?) lacrimula in Core 5, marks the transition from the Acaeniotyle umbilicata Zone to the Eucyrtis tenuis Zone. Core 5 (103-112 m) is considered to be Aptian to Barremian, Cores 6 and 7 (121-167 m) Barremian to Hauterivian or Valanginian. All three are assigned to the Eucyrtis tenuis Zone. Core 8 (195-204 m) is also Barremian to Hauterivian or Valanginian, and Core 9 (232$241 \mathrm{~m}$ ) is Valanginian. Both are assigned to the Sethocapsa trachyostraca Zone. Cores 10 to 12 (270-307 m) are Valanginian to Berriasian, Sphaerostylus lanceola Zone.

\section{SEDIMENTATION RATES}

Discontinuous coring, negligible sediment recovery, and poorly diversified fossil assemblages permit only gross estimates of sedimentation rates. At least 85 m.y. is represented in the 37-meter, uncored or unfossiliferous interval between the Quaternary top of Core 1 and early Late Cretaceous Core 2. An unconformity is probable.

When age-error estimates are applied to Early Cretaceous Cores 3 to 11 , sedimentation rates of 5 to 10 $\mathrm{m} / \mathrm{m} . \mathrm{y}$. are indicated. The average rate for Cores 2 to 11 is $7 \mathrm{~m} / \mathrm{m} . \mathrm{y}$. (269 m/40 m.y.). The highest rates would appear to be in the Berriasian? to Valanginian or Hauterivian interval of Cores 7 to 12 .

\section{SUMMARY AND CONCLUSIONS}

The estimate of Late Jurassic or Earliest Cretaceous as the age of magnetic anomaly M-21 is the most significant result of Site 307. This confirms the correlation of the Hawaiian lineations with the Keathley lineations in the North Atlantic (Larson and Pitman, 1972). It also indirectly confirms the correlation of the Phoenix, Japanese, and Hawaiian lineations (Larson and Chase, 1972) because the model used for this correlation was simply extended to the older anomalies for the worldwide correlation of Larson and Pitman (1972).

The basement age of Site 307 probably is not firmly enough established to be used as a calibration point for the Mesozoic reversal time scale. However, the age is determined closely enough that its limitations are interesting and deserve the following discussion.

The oldest fossils were recovered from Core 12 with weathered basalts underlying them. The sediments of Cores 11 and 12 are dated by Radiolaria whose occurrence is rare and diversity is poor. They are pre-early Valanginian in age and are known to co-exist with Tithonian to early Valanginian nannofossils from Legs 17 and 20 . Cores 11 and 12 are probably Berriasian in age because the upper portion of Core 10, 20 meters higher in the section, is late Valanginian or early Hauterivian, and the general Cretaceous sedimentation rates down to that level are relatively high $(5-10 \mathrm{~m} / \mathrm{m} . \mathrm{y}$.). Also, the pre-Valanginian radiolarians co-exist with younger forms found higher in the hole. By an extrapolation of the same argument, basement is prob- ably Berriasian in age. The Larson and Pitman time scale predicts Portlandian or Kimmeridgian as the basement age of M-21, which cannot be excluded because the Radiolaria have only an upward-bounded range. However, the geology of the hole suggests a basement age of approximately 5 to $10 \mathrm{~m}$.y. younger than this prediction.

This result does determine that the age progression of the M-sequence of reversals is correct, in that Site 307 is significantly older than Sites 303 and 304 that were drilled on magnetic anomalies predicted to be younger than M-21 at Site 307. Several possibilities exist that would account for the apparent age discrepancy. (1) The oldest age is poorly determined and may be significantly older than our best estimate, because the oldest calcareous material was recovered between 20 and 35 meters above basement. (2) A significant nondepositional interval may have occurred after extrusion of the basalt at Site 307. (3) The calibration of the radiometric time-scale of the Latest Jurassic-Earliest Cretaceous may be significantly in error. Some combination of these possibilities is probably the explanation for the basement age discrepancy.

The top 33 meters of the section is a brown, zeolitic pelagic clay that is the result of slow deposition in deep water north of the equatorial zone of productivity. Below that the zeolitic clay is mixed with porcellanite and chert of Middle Cretaceous age. These sediments are present down to at least 167 meters and probably indicate the time when Site 307 was moving across the zone of equatorial productivity. This probably occurred from the late Neocomian to the early Late Cretaceous (Cenomanian?). From 195 meters down to basement at 298 meters the cherts and porcellanites are mixed with calcareous material indicating probable deposition at ridge crest depths from the middle Neocomian down to the basement of Berriasian age. The sedimentation rates yield this same generalized picture that indicates deposition at 5 to $10 \mathrm{~m} / \mathrm{m}$.y. from early Late Cretaceous down to basement.

The cherts at this deep site are markedly different from the Shatsky Rise cherts. Many of them are made up of softer porcellanite with a much lower sound velocity. They contain much better preserved radiolarian specimens, and their drilling characteristics seem to indicate that they occur in thicker lenses.

The basement lava is very obviously of extrusive origin, consisting of several thin flow units and a large percentage of hyaloclastite. It is extremely weathered material, the upper portion now being greenish-gray clay with only the ghosts of the former plagioclase and pyroxene grains indicating its igneous origin. The deeper basalts are less severely altered and possess a hard remnant magnetic component. A summary of Site 307 data appears in Figure 4.

\section{REFERENCES}

Chase, T.E., Menard, H.W., and Mammerickx, J., 1971. Topography of the north Pacific: Institute of Marine Resources, University of California, San Diego.

Jones, J.B. and Segnit, E.R., 1971. The nature of opal. I. nomenclature and constituent phases: J. Geol. Soc. Australia, v 18, p. 57. 
Larson, R.L. and Chase, C.G., 1972. Late Mesozoic evolution of the Western Pacific: Geol. Soc. Am. Bull., v. 83, p. 36273644.
Larson, R.L. and Pitman, W.C., III, 1972. World-wide correlation of Mesozoic magnetic anomalies, and its implications: Geol. Soc. Am. Bull., v. 83, p. 3645-3663.

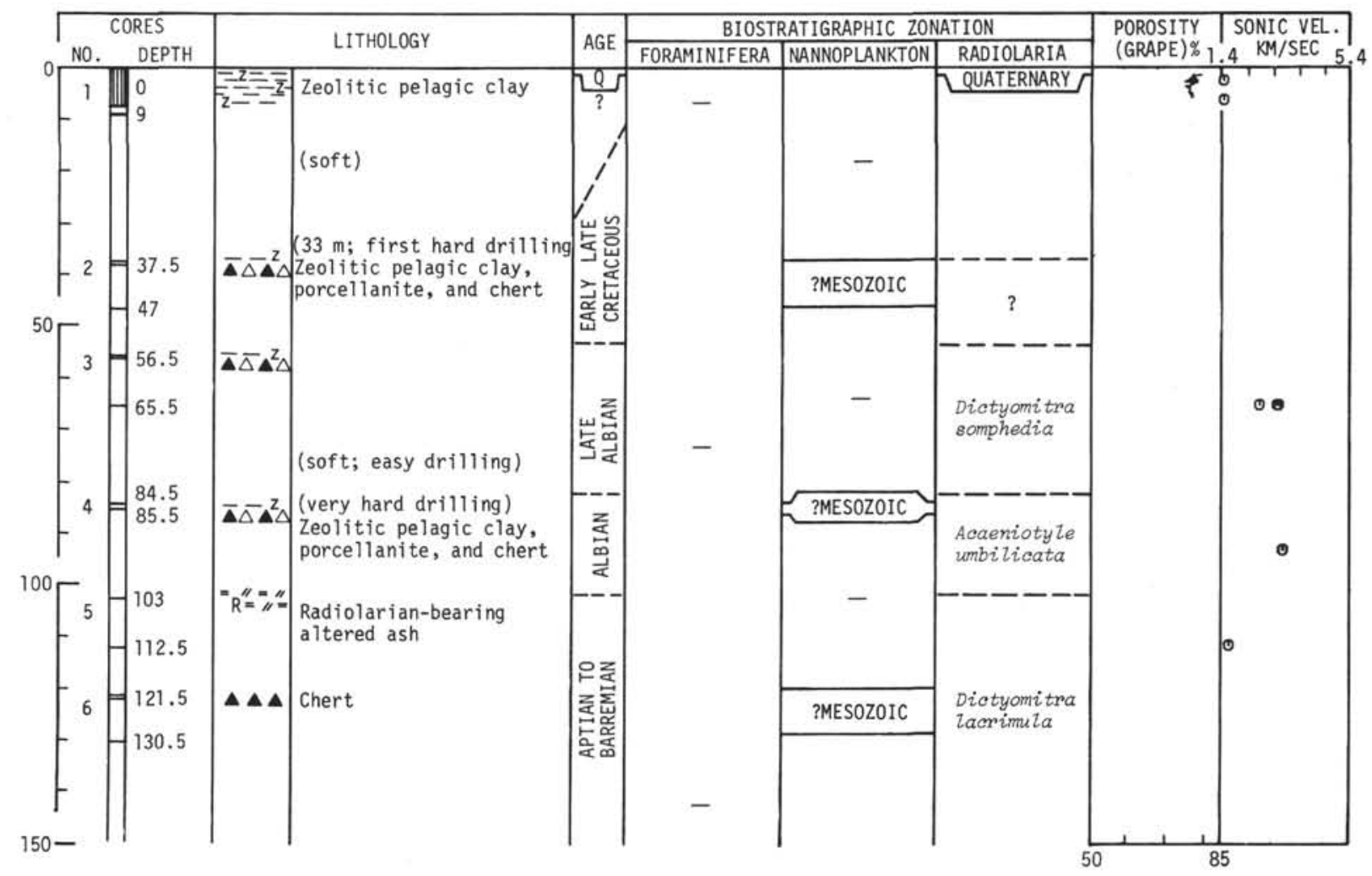

Figure 5. Summary of coring, lithology, biostratigraphy, and physical properties at Site 307.

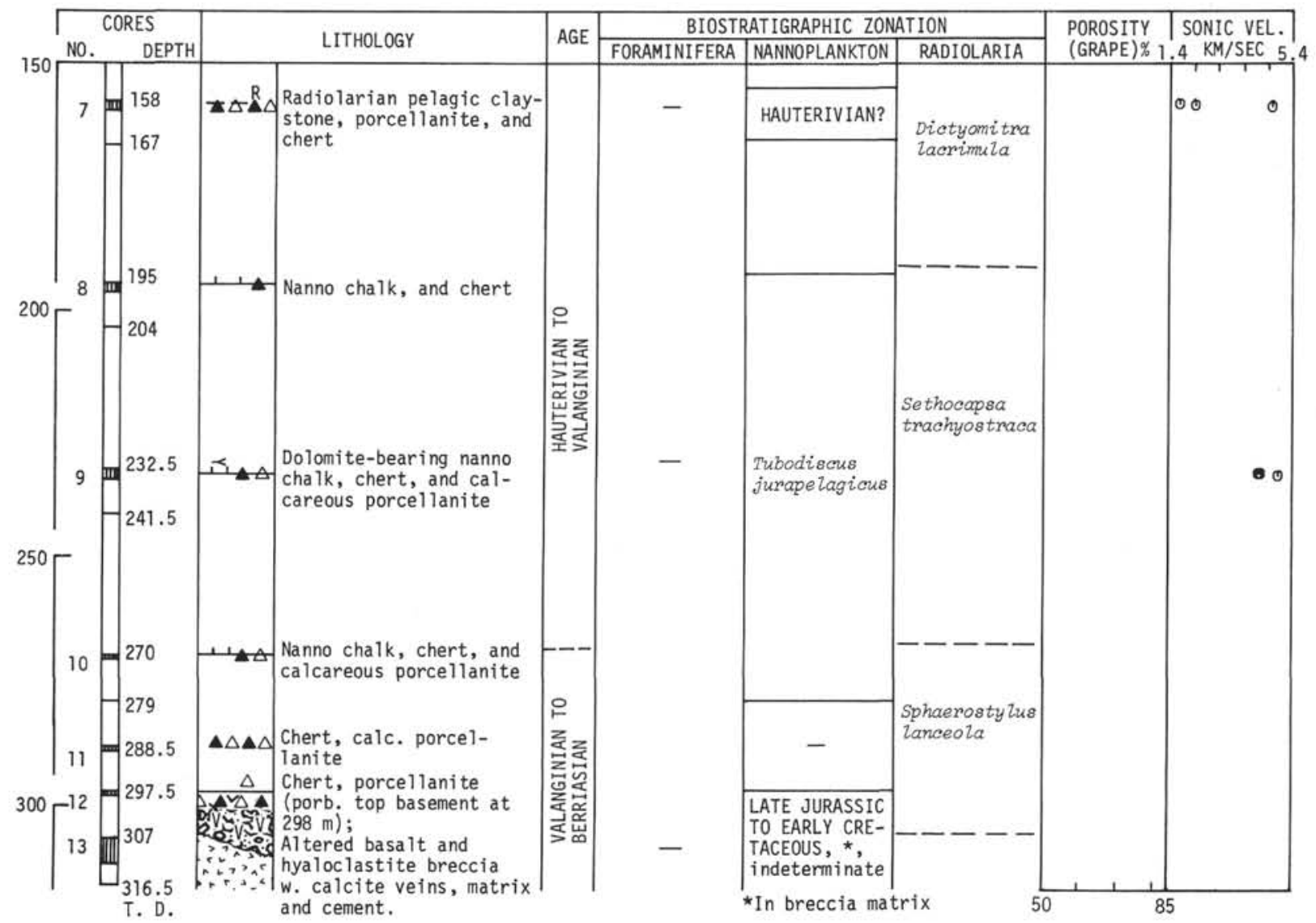

Figure 5. (Continued). 


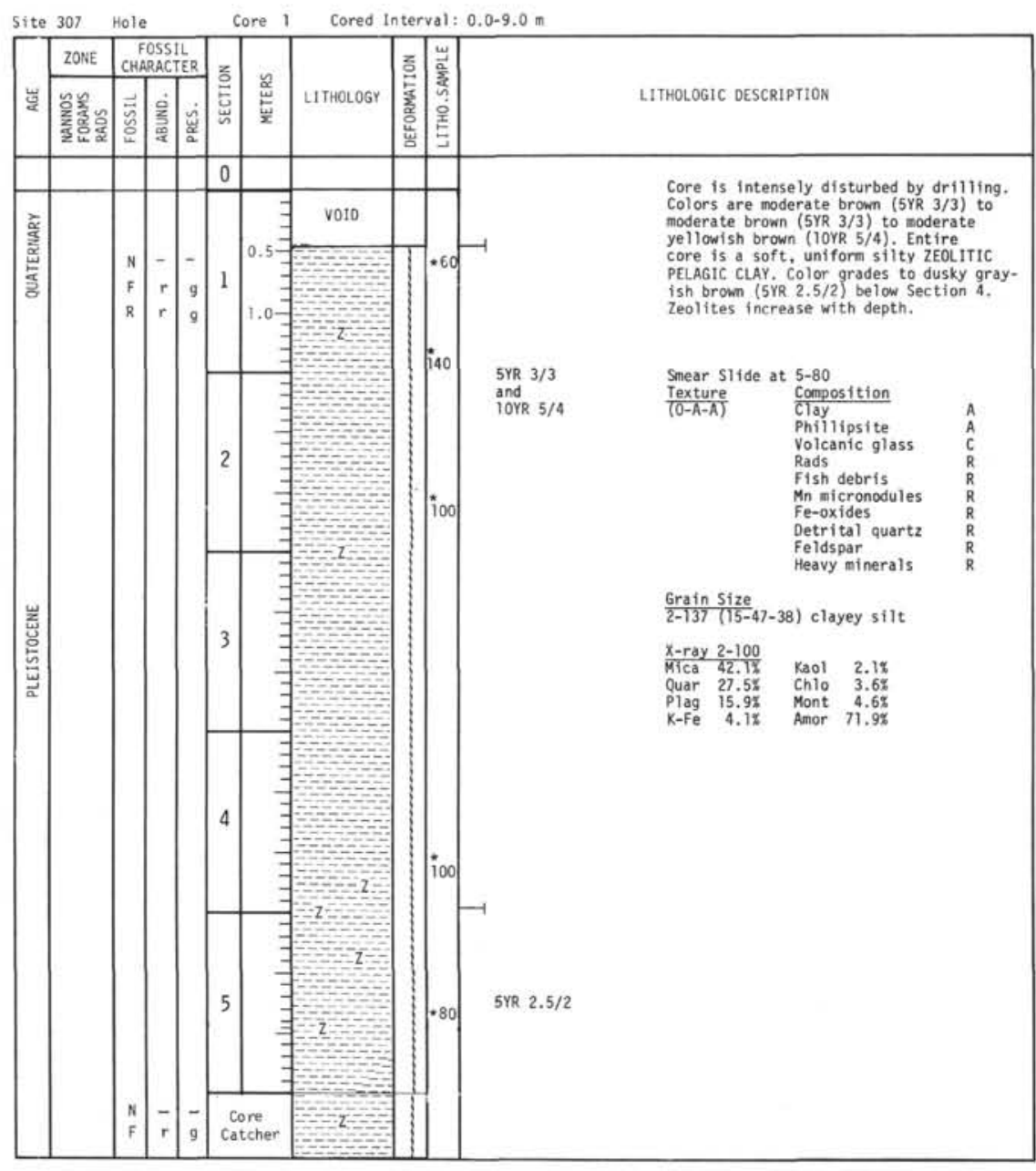

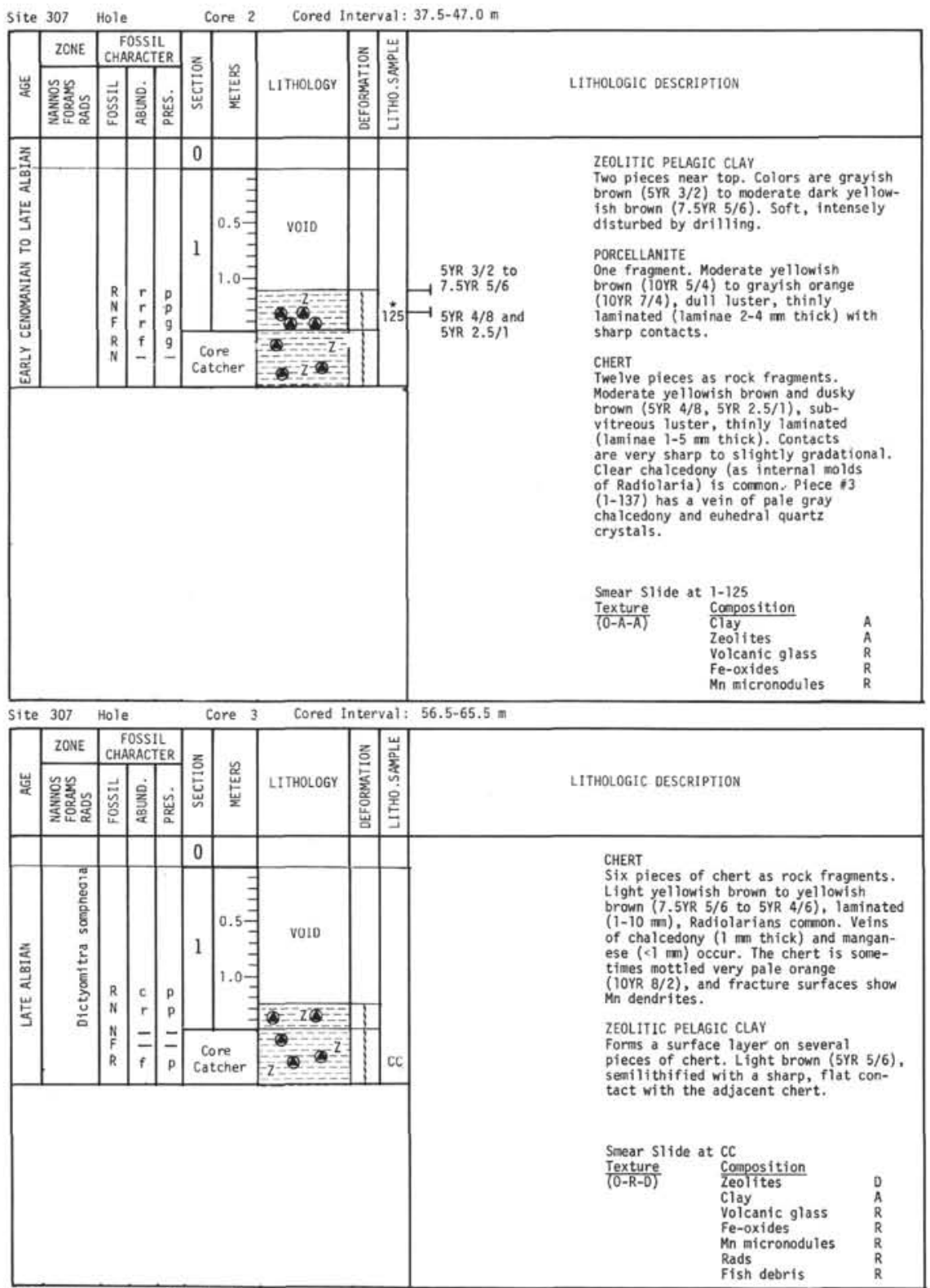

Explanatory notes in Chapter 1 


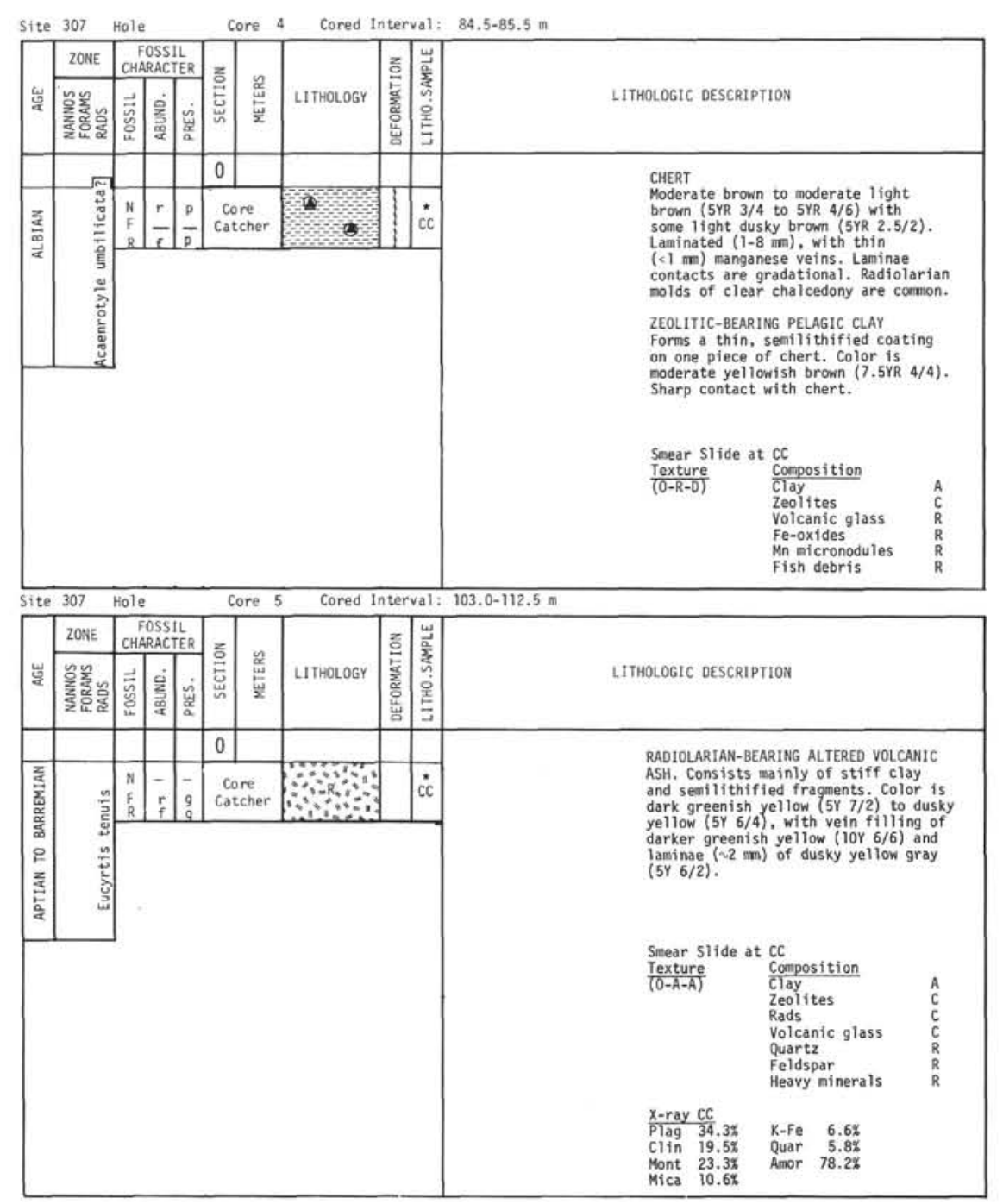

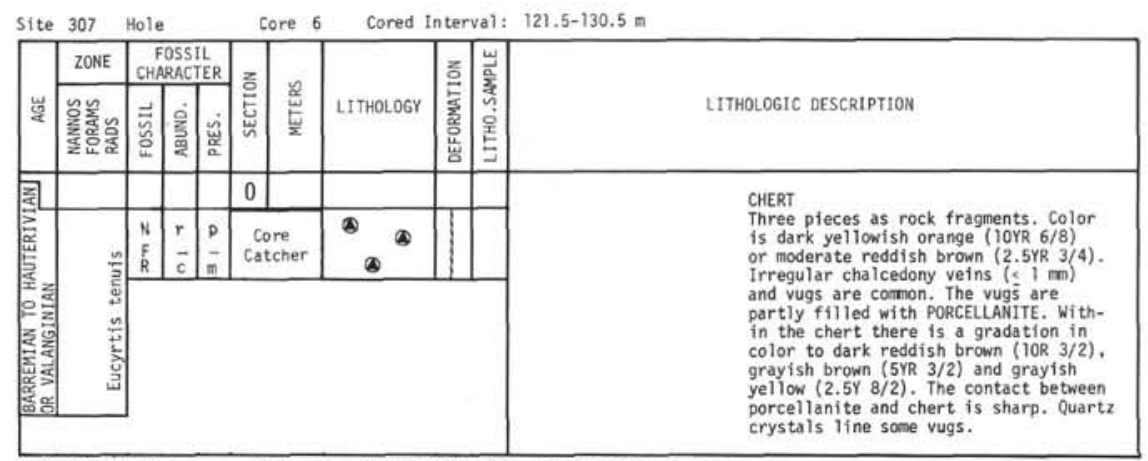

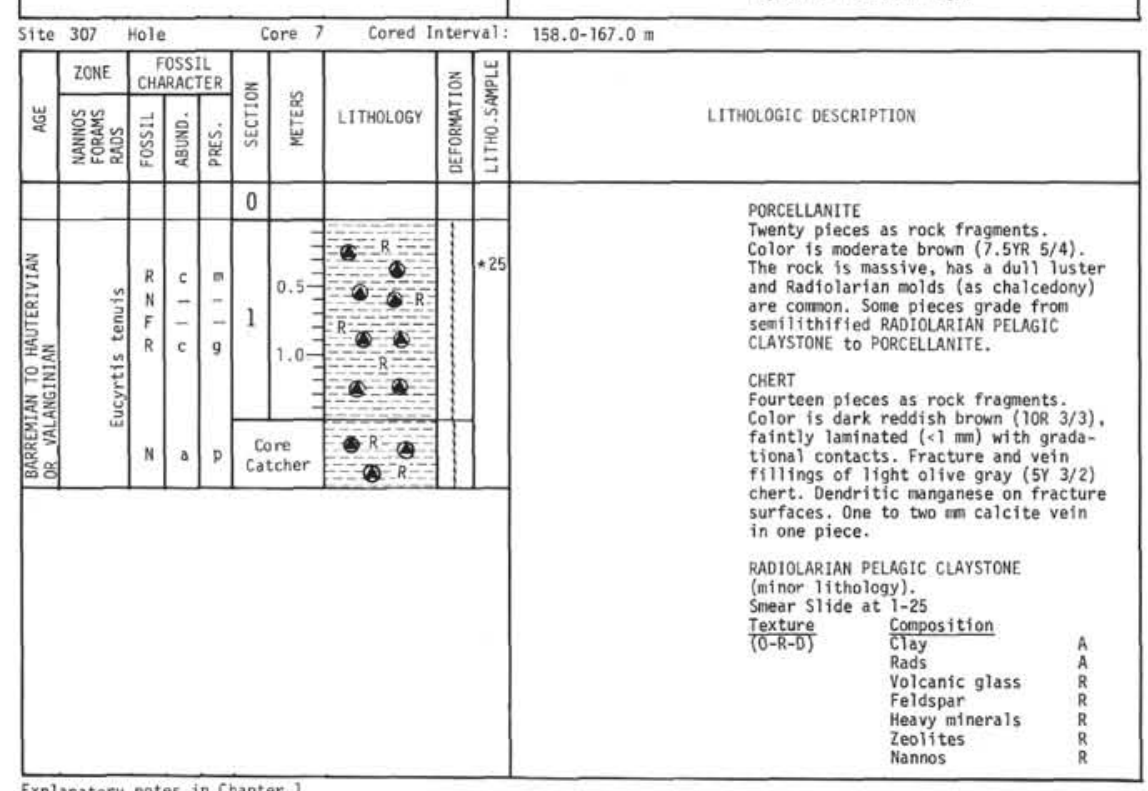

Explanatory notes in Chapter 1 


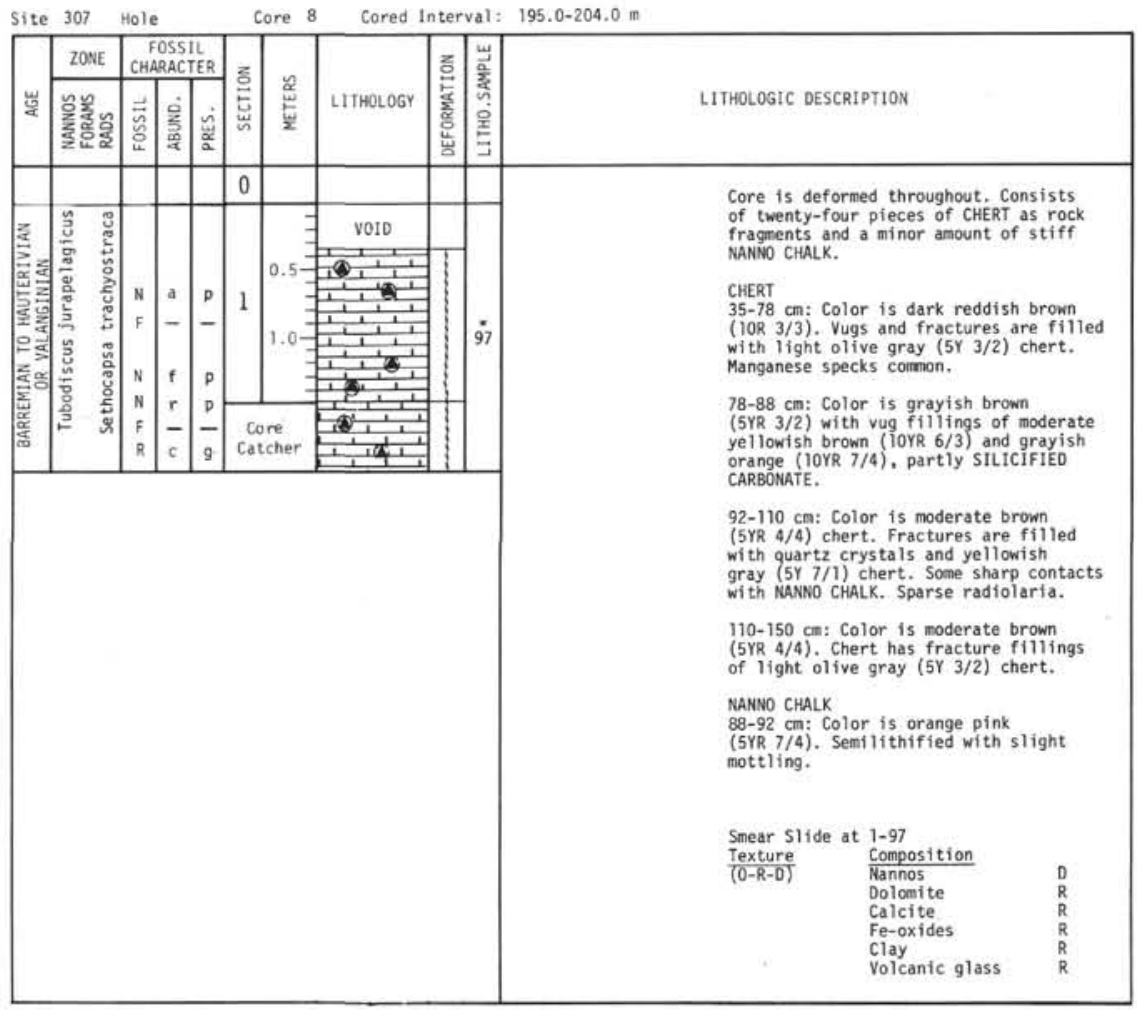

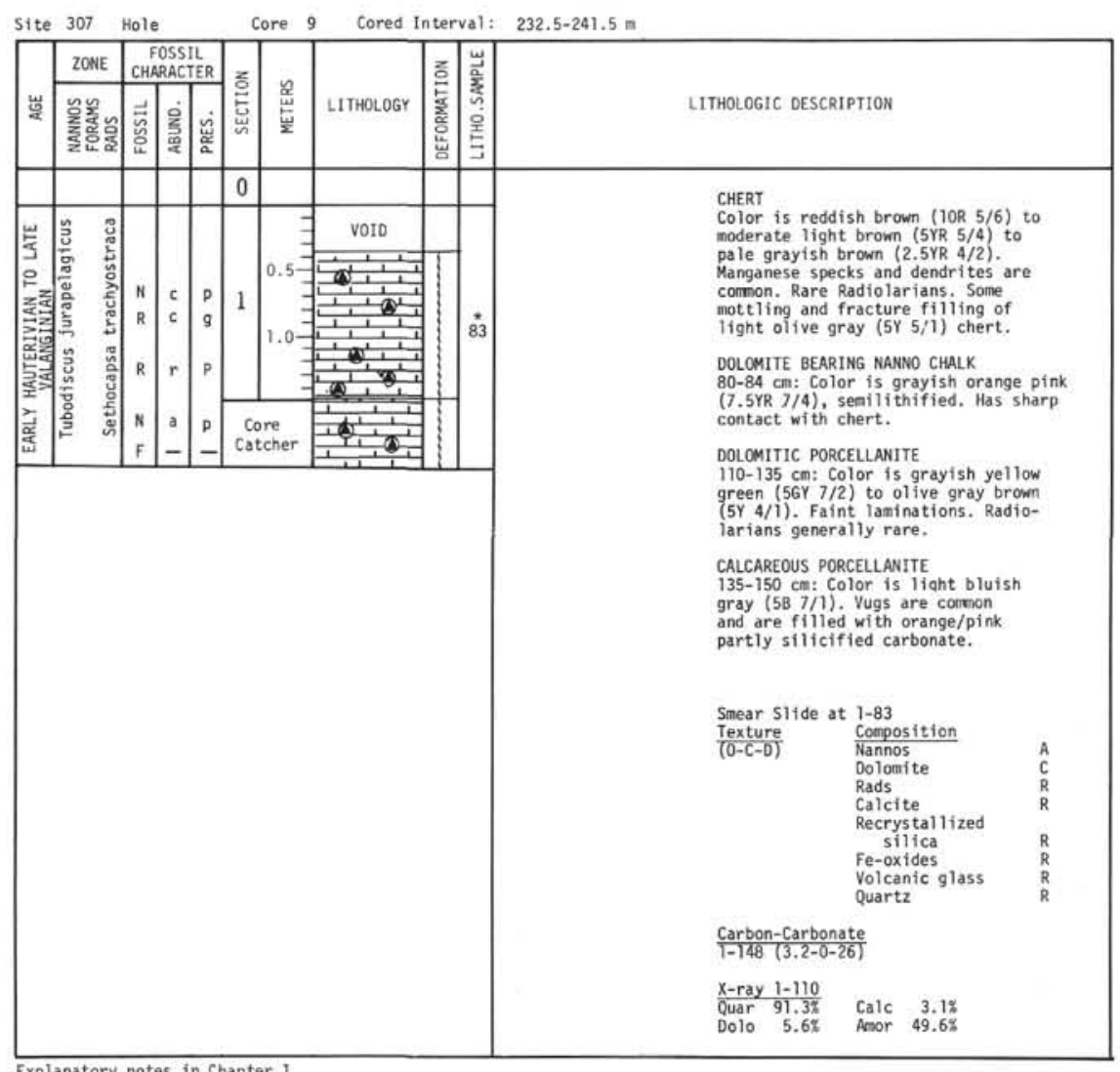




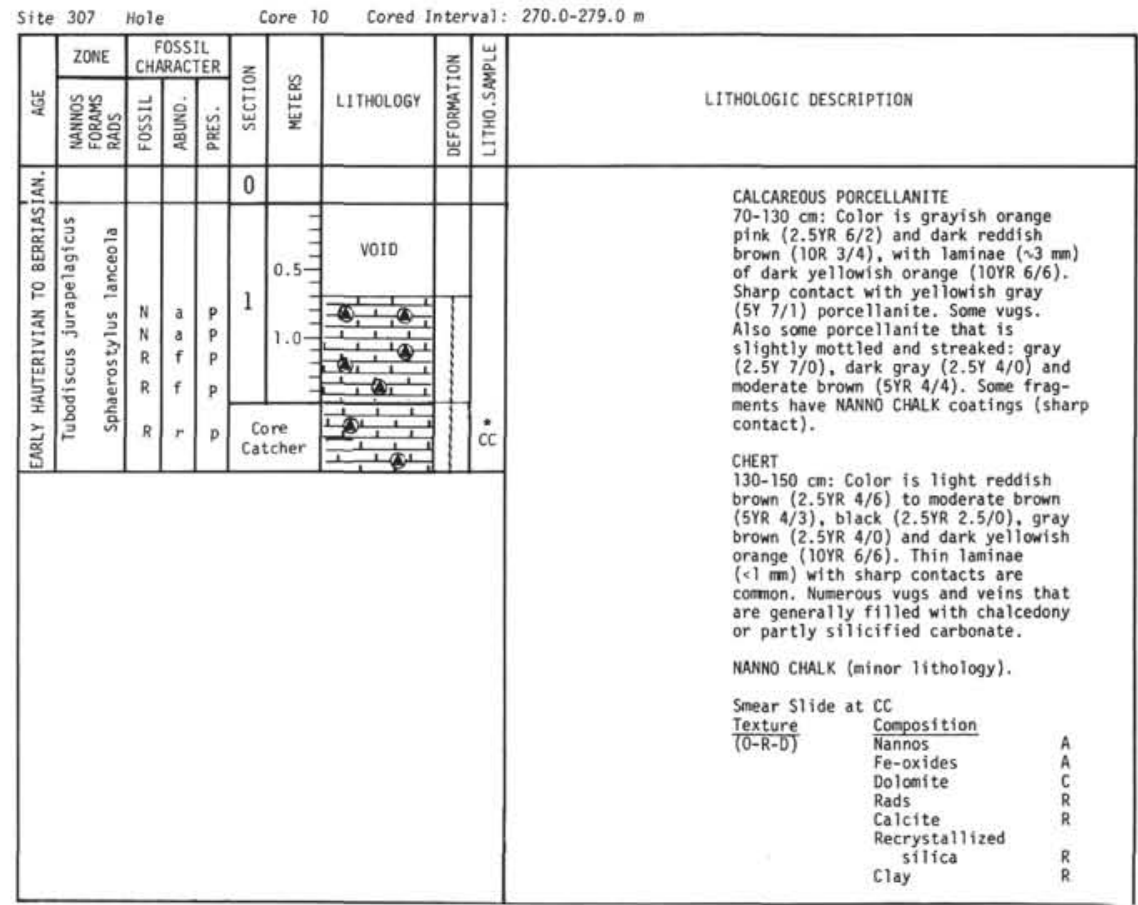

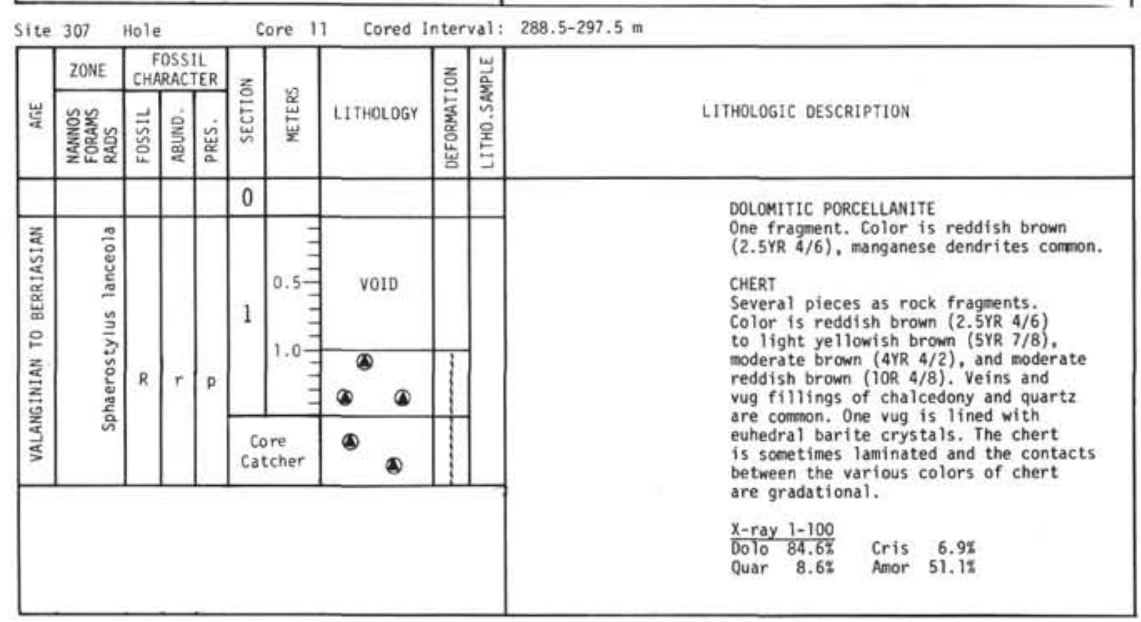

\begin{tabular}{|c|c|c|c|c|c|c|c|c|}
\hline ite & 307 & Hole & & & & re 12 & cored I & iterv \\
\hline & ZONE & $\begin{array}{l}F 0 \\
\text { CHAR }\end{array}$ & OSSIT & & & & & $z$ \\
\hline 岁 & 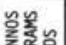 & $\overrightarrow{0}$ & อ. & $\dot{\varphi}$ & 吾 & 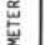 & LITHOLOGY & 氕 \\
\hline & & & & & 0 & & & \\
\hline & & & & & & & & \\
\hline 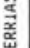 & : & & & & & 0.57 & V010 & \\
\hline 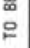 & & & & -1 & 1 & & & \\
\hline$\frac{3}{z}$ & & $\begin{array}{l}R \\
N\end{array}$ & & $p$ & & & $9=$ & \\
\hline 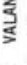 & & & & & $\begin{array}{l}\text { Core } \\
\text { Catch }\end{array}$ & & $\because \because$ & \\
\hline
\end{tabular}

LITHOLOGIC DESCRIPTION

Eerruginous SILICEOUS PELAGIC CLAYSTONE,
Color is moderate red brown $(2.5 Y R \quad 3 / 6)$. Sthified and massive with Mn blebs $\frac{\text { Thexture }}{\text { Tox }(0-c-0)}$

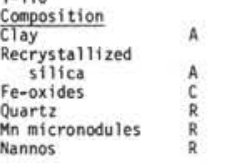

Tho fragnents. Color is dark yellow common and filled with aurtz vugs are

Smear slide at 1-135 (vein filling)

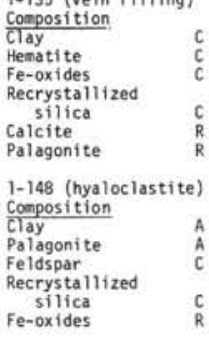

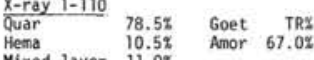

$\frac{x-\text { ray CC }}{\text { K-Fe } 51.4 \pi}$ Kao1 $7.1 \%$

$\begin{array}{llll} & \\ \text { Mont } & 32.92 & \text { Quar } 7.1 \% \\ \text { Anat } 1.3 \% & \text { Q Aaror } 58.3 \%\end{array}$

ALTERED BASALT (HYALOCLASTITE). Semibreccia with hematite and calcite. velins contron. Each fragment has con-
centric color zones: grayish orange pink (SFR $7 / 3)$, grayish yellow orange (10YR 7/6), dark reddish brown
$(10 R 3 / 3)$, pale yellow green (10GY $7 / 2)$.

Explanatory notes in Chapter 1 


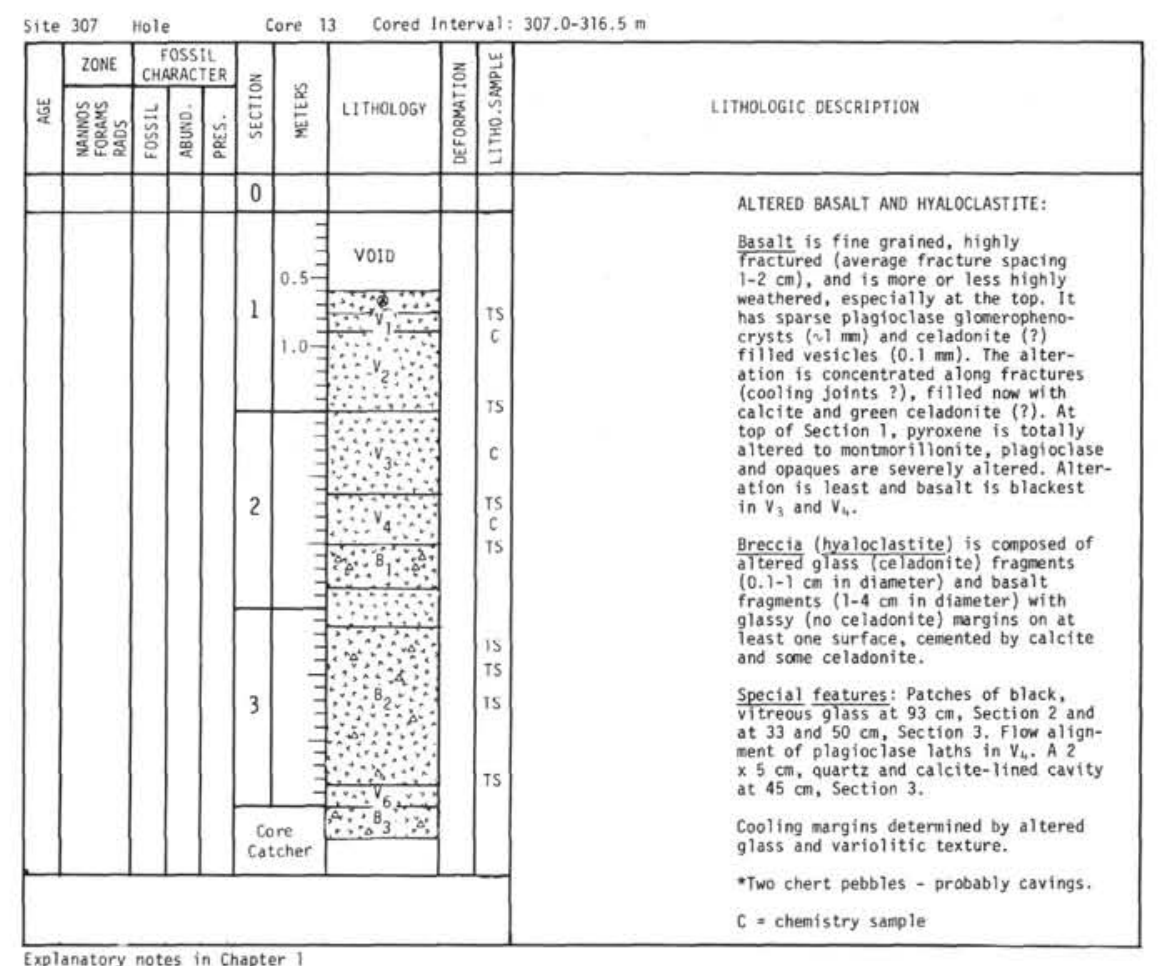


$=$ GRAPE WET-BULK DENSITY, $g / c c$

○ Syringe porosity, \%

COMPRESSIONAL SOUND VELOCITY

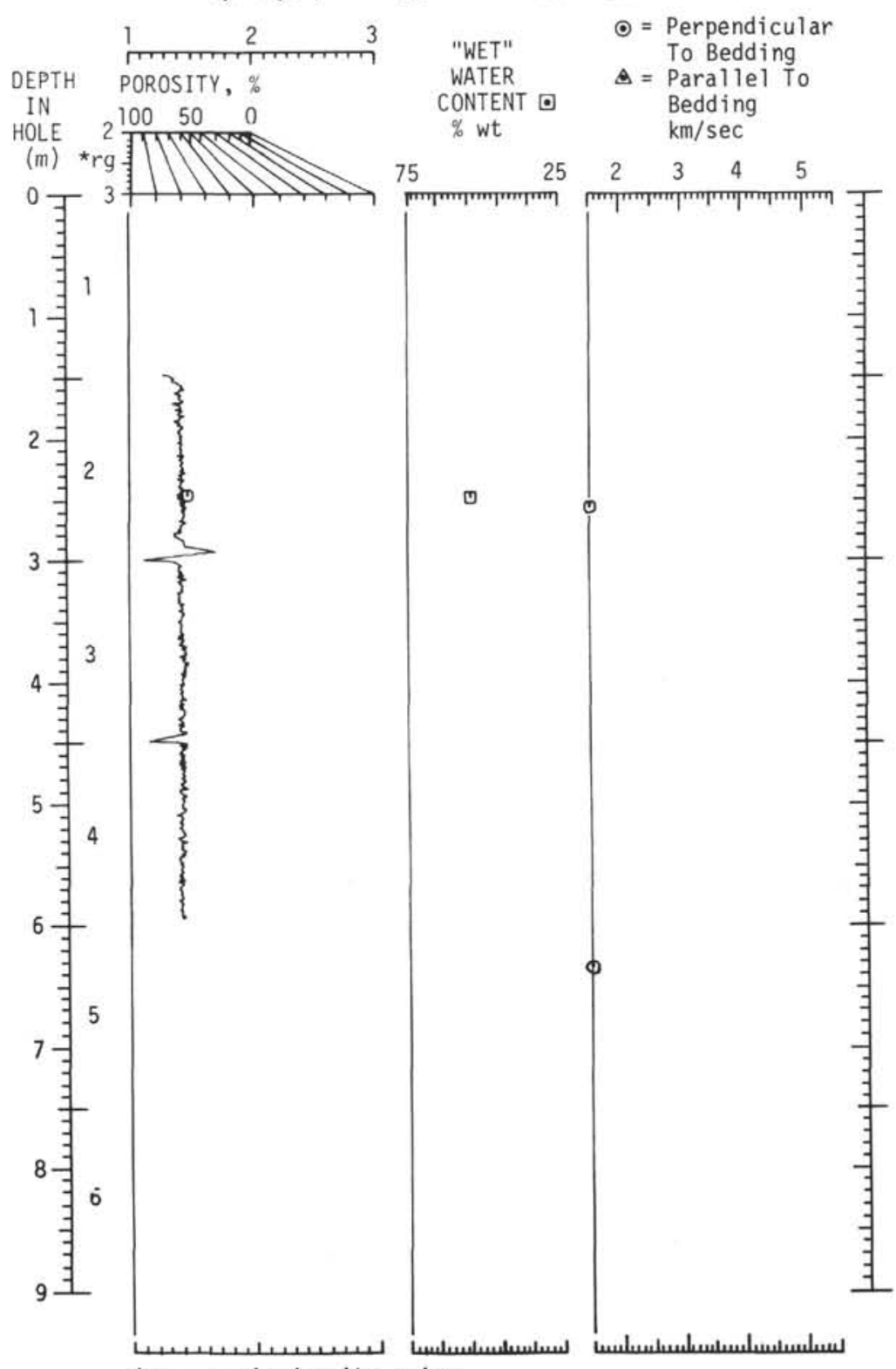

O = Perpendicular o Bedding

$=$ Parallel To

Bedding

${ }^{*} r g=$ grain density, $g / c c$
- $=$ GRAPE WET-BULK DENSITY, $\mathrm{g} / \mathrm{cc}$

- Syringe porosity, \% COMPRESSIONAL SOUND VELOCITY

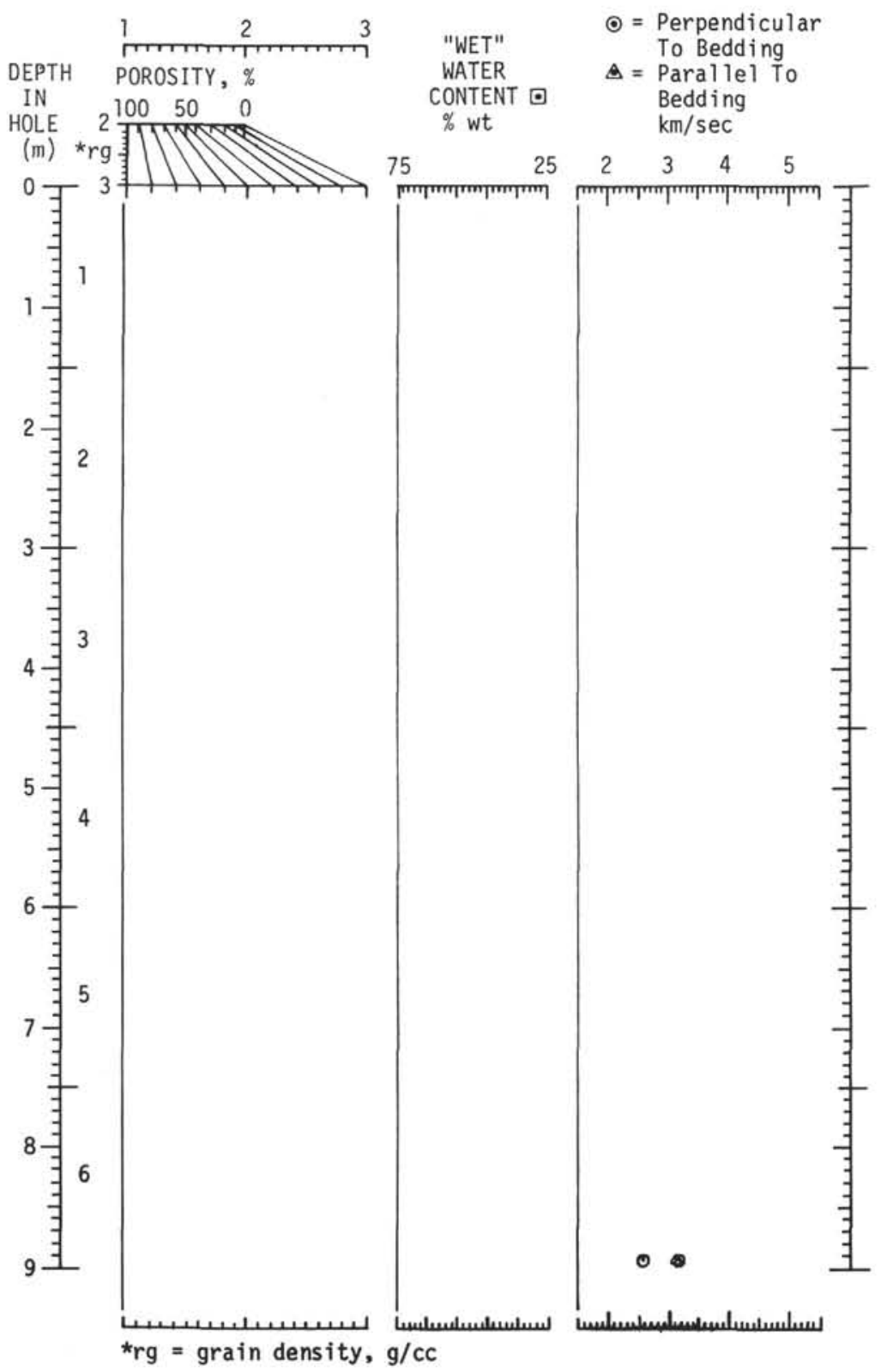


CORE $\quad 307-4$

- = GRAPE WET-BULK DENSITY, $\mathrm{g} / \mathrm{cc}$

○ Syringe porosity, \%

COMPRESSIONAL SOUND VELOCITY

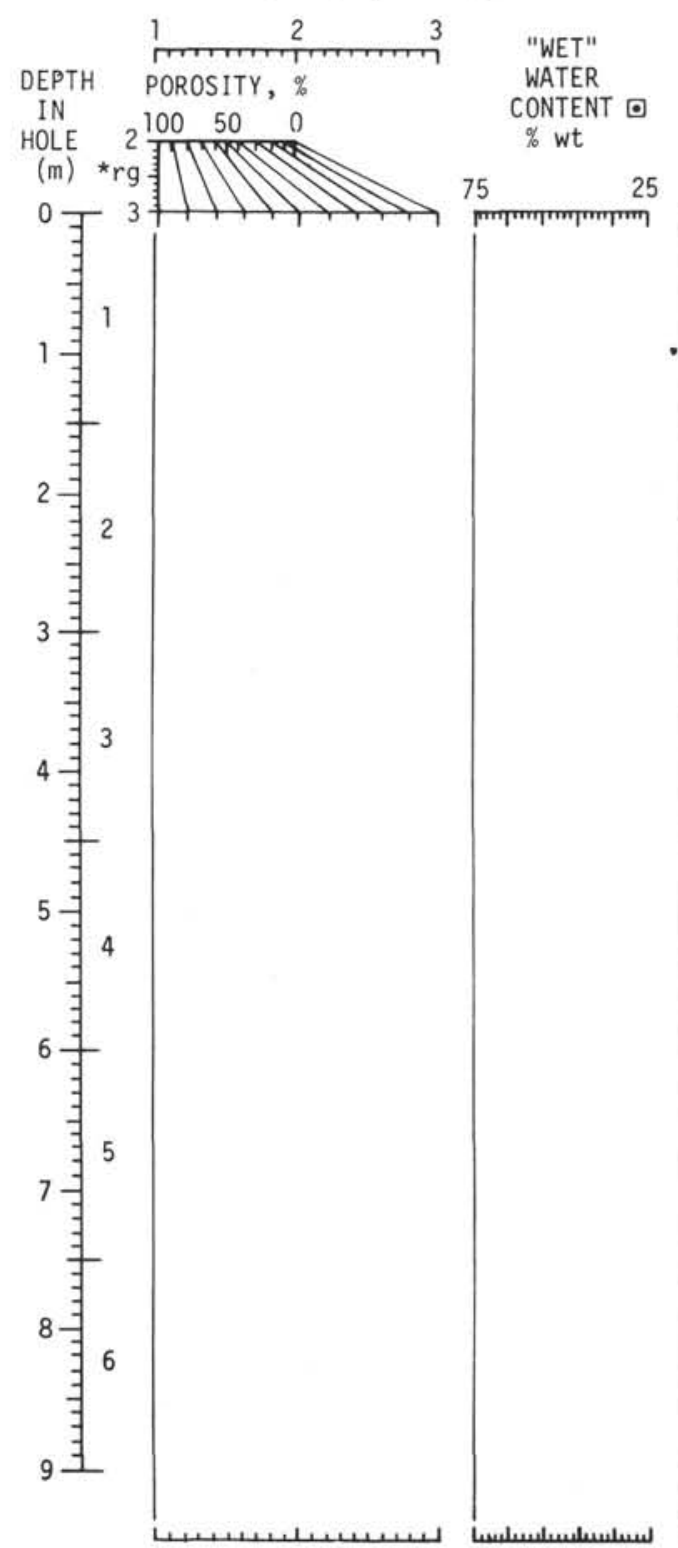

$\odot=$ Perpendicular

To Bedding

Bedding

$\mathrm{km} / \mathrm{sec}$

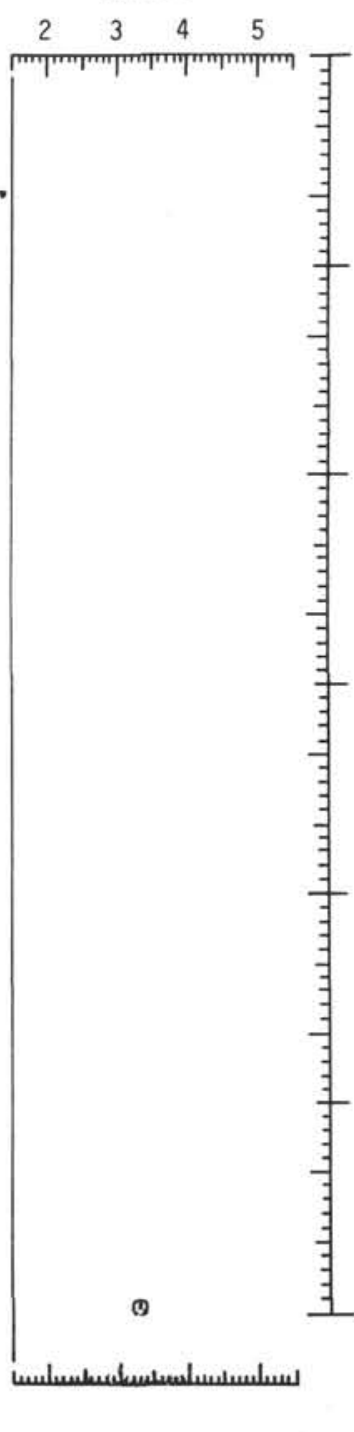

CORE $307-5$

- = GRAPE WET-BULK DENSITY, g/cC

- Syringe porosity, \% COMPRESSIONAL SOUND VELOCITY

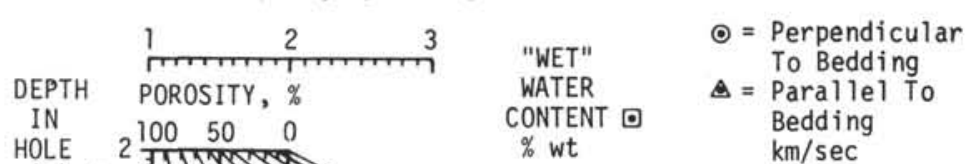

HOLE $2100 \quad 50 \quad 0 \quad \%$ wt

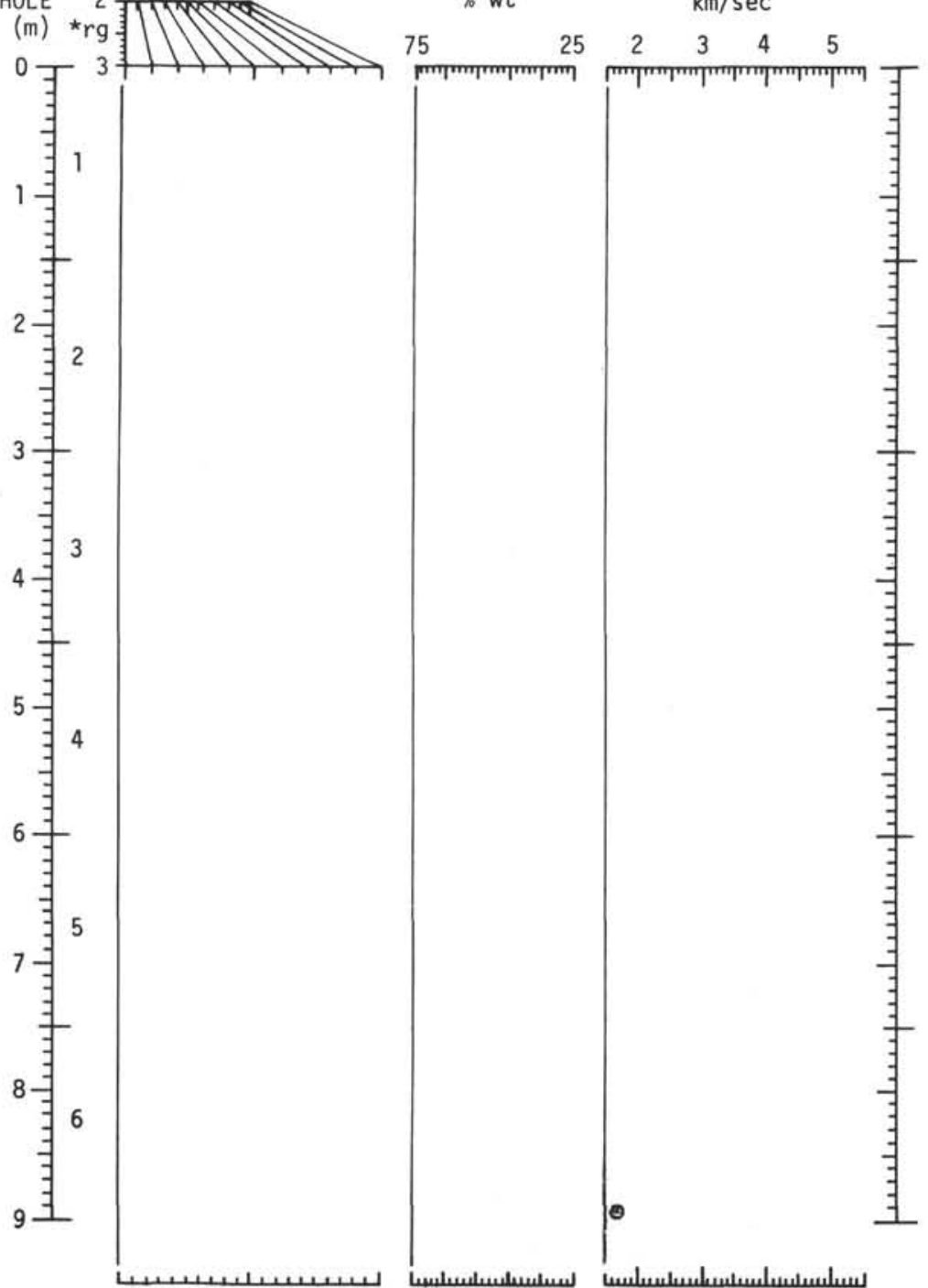

${ }^{*} r g=$ grain density, $\mathrm{g} / \mathrm{cc}$ 
- $=$ GRAPE WET-BULK DENSITY, $g / c c$

- Syringe porosity, \% COMPRESSIONAL SOUND VELOCITY

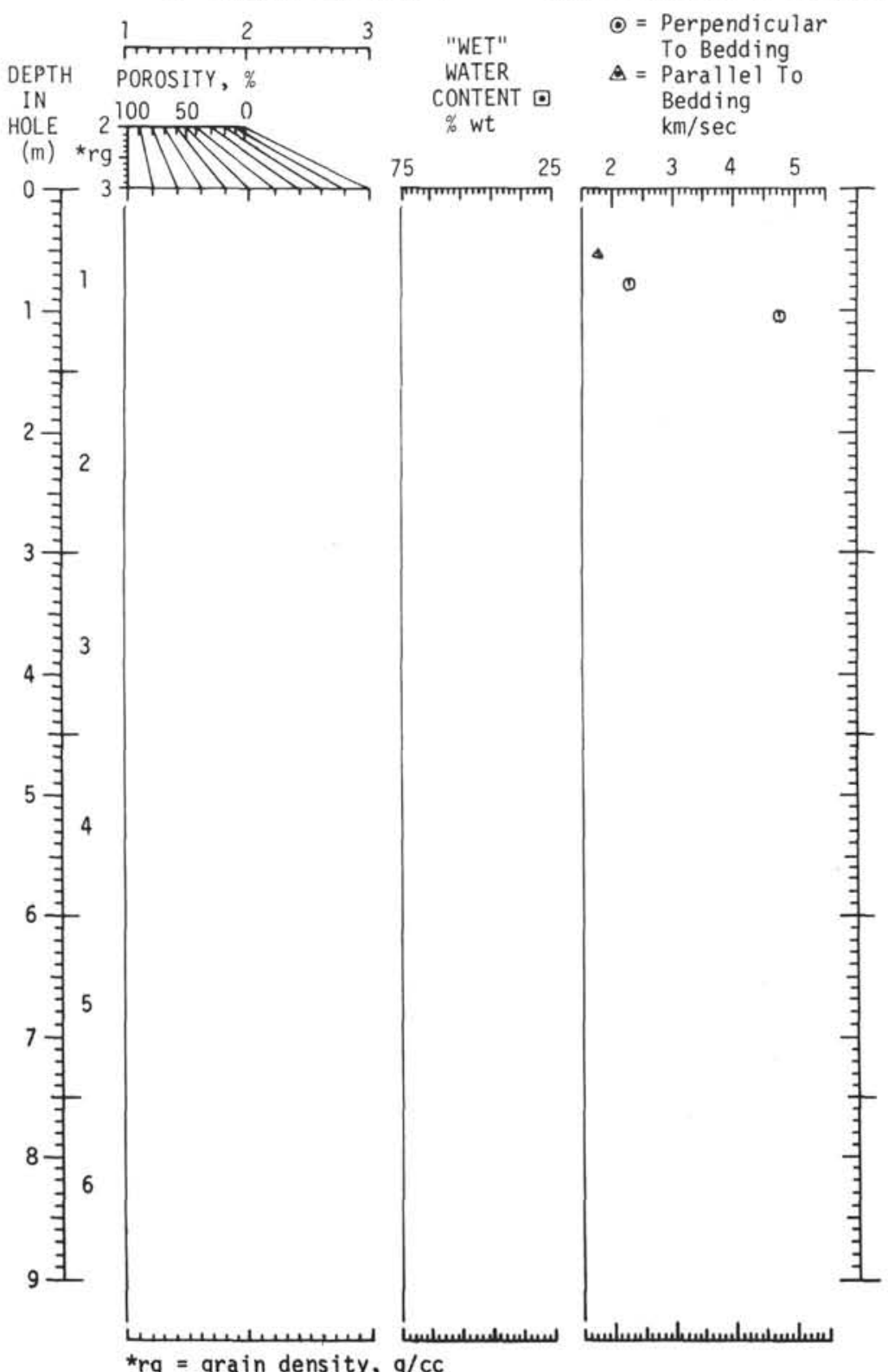

- = GRAPE WET-BULK DENSITY, g/cC

○ Syringe porosity, \%

COMPRESSIONAL SOUND VELOCITY

$\begin{array}{rlll} & 1 & 2 & \\ \text { DEPTH } & \text { POROSITY, } \% & \text { "WET" } & \text { Perpendicular } \\ \text { IN } & \text { To Bedding }\end{array}$

IN $10050 \quad 0 \quad$ CONTENT $\square$ Bedding

(m)*rg ${ }^{2}$ गा

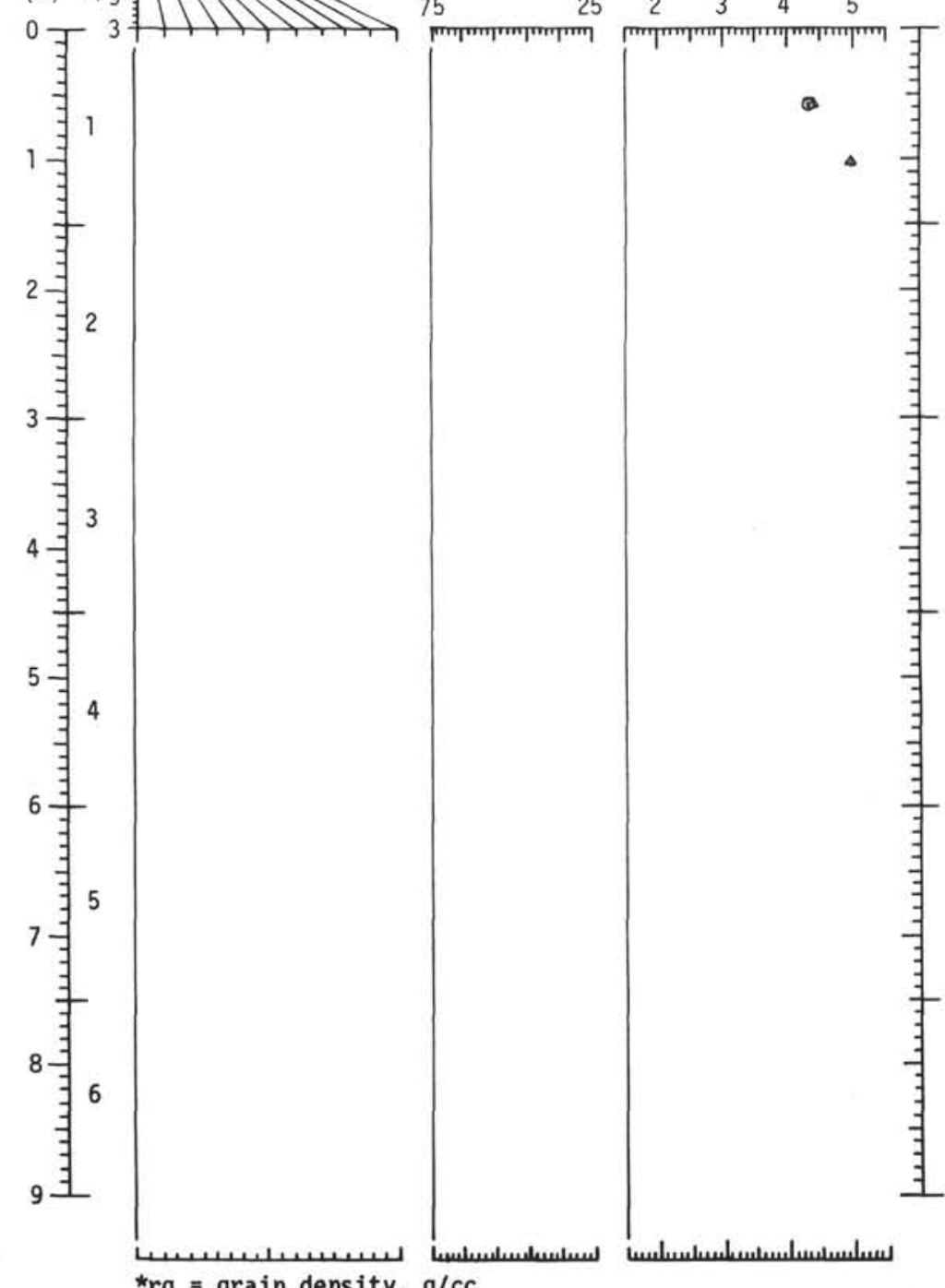


CORE 307-13

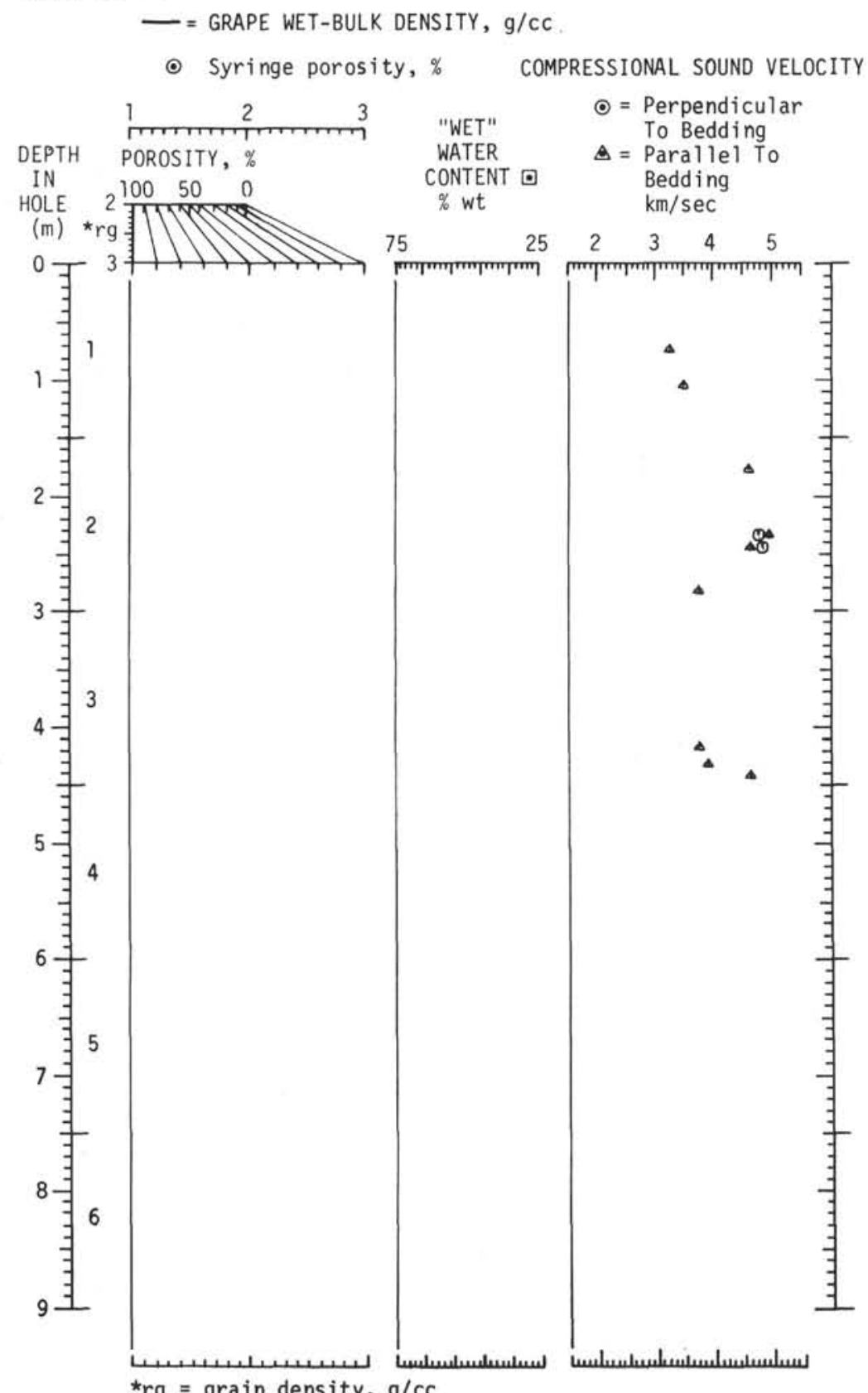




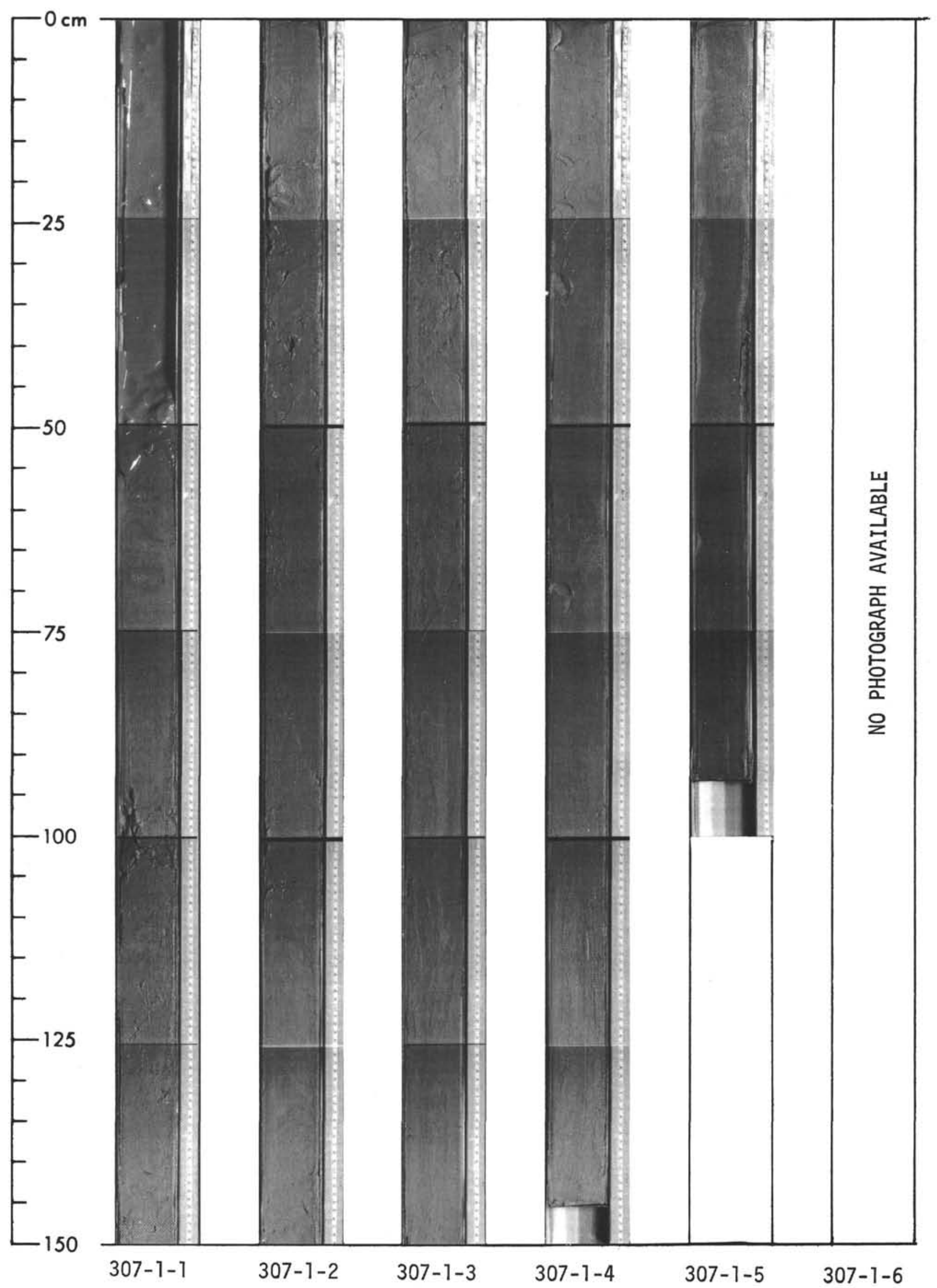




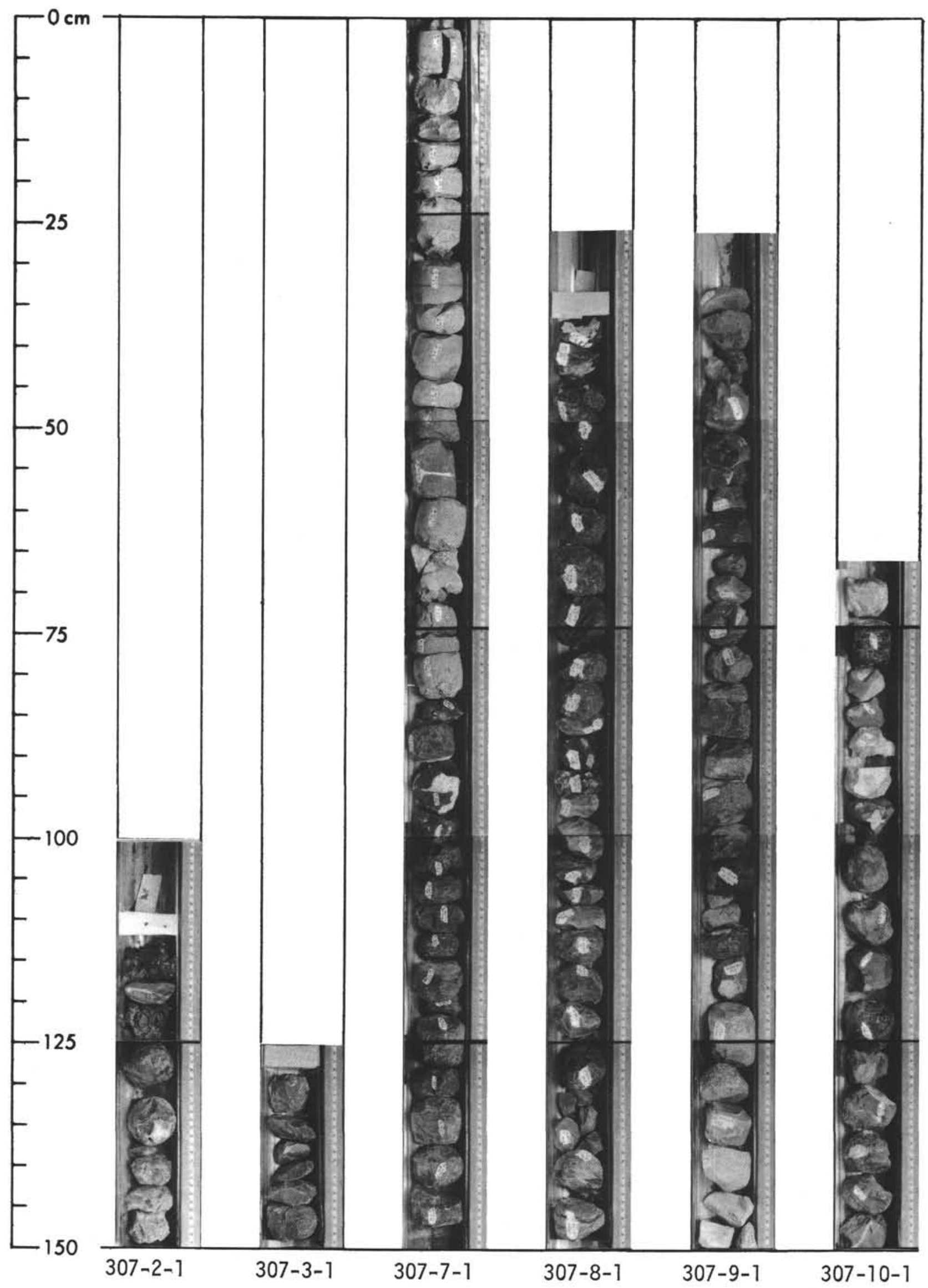




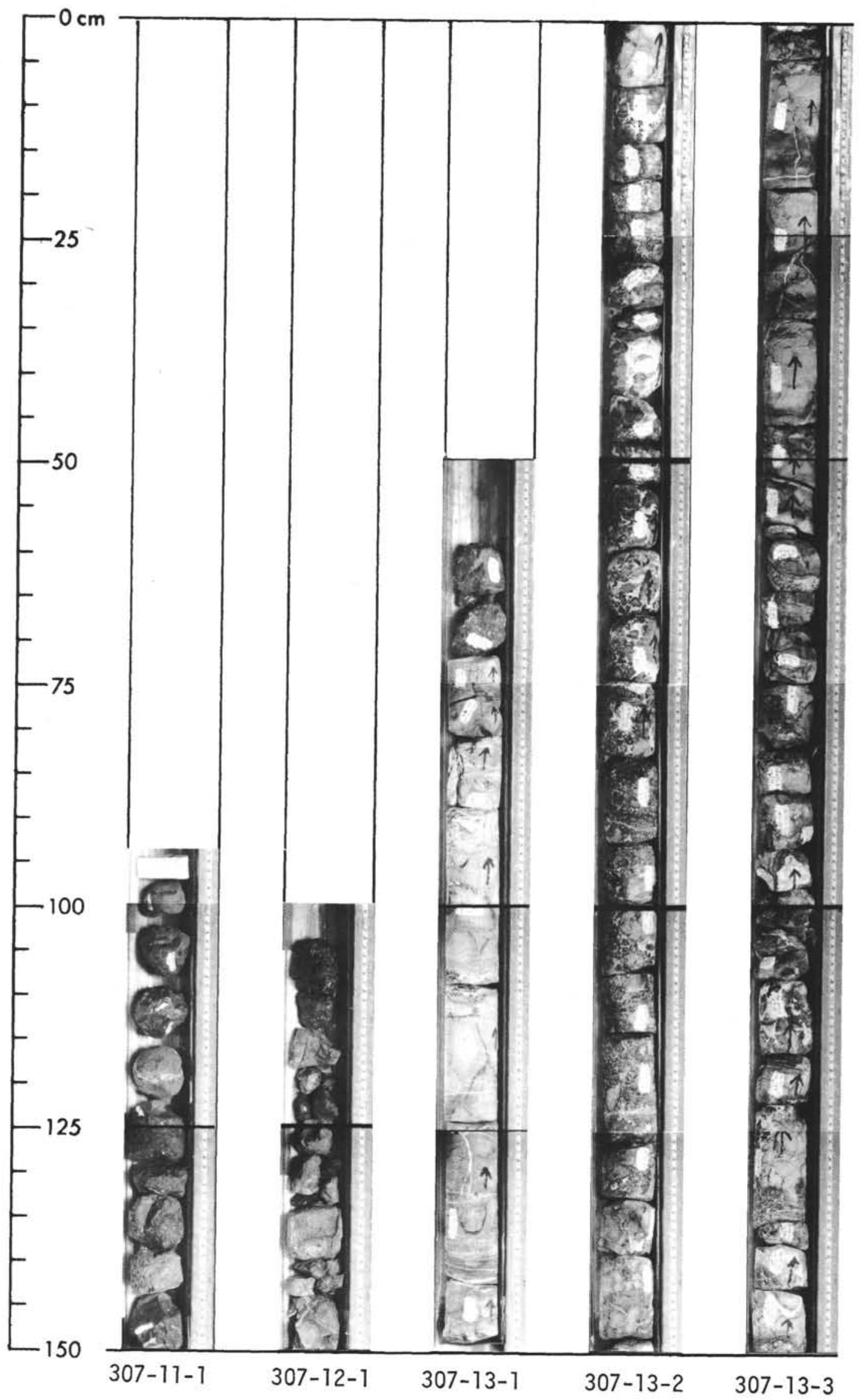

